\title{
Biomarkers of Acute Kidney Injury
}

\author{
Vishal S. Vaidya ${ }^{1}$, Michael A. Ferguson ${ }^{2}$, and Joseph V. Bonventre ${ }^{3}$ \\ ${ }^{1}$ Renal Division, Department of Medicine, Brigham and Women's Hospital, Harvard Medical School, \\ Boston, Massachusetts 02115; email: vvaidya@partners.org \\ 2Division of Nephrology, Children's Hospital Boston, Boston, Massachusetts 02115; email: \\ michael.ferguson@childrens.harvard.edu \\ ${ }^{3}$ Renal Division, Department of Medicine, Harvard Medical School, Boston, Massachusetts 02115; \\ email: joseph bonventre@hms.harvard.edu
}

\section{Abstract}

Acute kidney injury (AKI) is a common condition with a high risk of death. The standard metrics used to define and monitor the progression of AKI, such as serum creatinine and blood urea nitrogen levels, are insensitive, nonspecific, and change significantly only after significant kidney injury and then with a substantial time delay. This delay in diagnosis not only prevents timely patient management decisions, including administration of putative therapeutic agents, but also significantly affects the preclinical evaluation of toxicity thereby allowing potentially nephrotoxic drug candidates to pass the preclinical safety criteria only to be found to be clinically nephrotoxic with great human costs. Studies to establish effective therapies for AKI will be greatly facilitated by two factors: (a) development of sensitive, specific, and reliable biomarkers for early diagnosis/prognosis of AKI in preclinical and clinical studies, and $(b)$ development and validation of high-throughput innovative technologies that allow rapid multiplexed detection of multiple markers at the bedside.

\section{Keywords}

acute renal failure; clusterin; cystatin-C; cysteine-rich protein-61 (CYR-61); ELISA; Interleukin-18 (IL-18); kidney injury molecule-1 (Kim-1); microfluidics; nanotechnology; neutrophil gelatinaseassociated lipocalin (NGAL)

\section{ACUTE KIDNEY INJURY}

\section{Definition and Prevalence}

Acute kidney injury (AKI) is currently recognized as the preferred nomenclature for the clinical disorder formally called acute renal failure (ARF). This transition in terminology served to emphasize that the spectrum of disease is much broader than that subset of patients who experience failure requiring dialysis support (1). This new nomenclature underscores the fact that kidney injury exists along a continuum: The more severe the injury, the more likely the overall outcome will be unfavorable. The Acute Kidney Injury Network (AKIN), which was formed recently in an effort to facilitate improved care of patients who are at risk for AKI, described AKI as "functional or structural abnormalities or markers of kidney damage

\footnotetext{
Copyright $\odot 2008$ by Annual Reviews. All rights reserved

The Annual Review of Pharmacology and Toxicology is online at http://pharmtox.annualreviews.org

DISCLOSURE STATEMENT

Dr. Bonventre is a co-inventor on patents involving KIM-1.
} 
including abnormalities in blood, urine, or tissue tests or imaging studies present for less than three months." AKI is associated with the retention of creatinine, urea, and other metabolic waste products that are normally excreted by the kidney. Although severe AKI may result in oliguria or even anuria, urine volume may be normal or even increased (2).

Recent epidemiologic data suggest that the progress observed in the understanding of the pathophysiology of AKI and in the clinical care of patients with AKI has failed to yield commensurate improvements in clinical outcomes. AKI has been reported to complicate $1 \%$ to $7 \%(3,4)$ of all hospital admissions and $1 \%$ to $25 \%$ of intensive care unit (ICU) admissions (5). Over the past 50 years, mortality rates of patients with AKI in the ICU have remained high, at approximately $50 \%$ to $70 \%$. Although there is some indication that mortality rates may be falling, the incidence of AKI has increased greatly over time (6). A recent large international study of the epidemiology and outcome of AKI in critically ill adult patients reported an overall in-hospital mortality rate of 60\% (7). Of those who survived to hospital discharge, $13 \%$ remained dialysis-dependent. In a smaller retrospective study of 267 adult AKI survivors requiring acute renal replacement therapy, renal insufficiency persisted in $41 \%$ and overall 5year survival postdischarge was $50 \%$ (8).

\section{Pathophysiology and Mechanisms}

Acute kidney injury can result from decreased renal or intrarenal perfusion, a toxic or obstructive insult to the renal tubule, tubulointerstitial inflammation and edema, or primary reduction in the filtering capacity of the glomerulus (9). Ischemia and toxins, often in the setting of sepsis, account for the largest number of cases of AKI. Ischemia and toxins often combine to cause AKI in severely ill patients with conditions such as sepsis, hematologic cancers, or the acquired immunodeficiency syndrome. It is estimated that 19\%-33\% of in-hospital AKI cases are attributed to drug nephrotoxicity $(10,11)$. Antibiotics, in particular aminoglycosides such as gentamicin and tobramycin, were the most frequently cited nephrotoxic drugs, followed by analgesics, NSAIDs, and contrast media. Other compounds that can potentially result in AKI include chemotherapeutic agents such as cisplatin; immunosuppressants such as cyclosporine and tacrolimus; environmental contaminants such as cadmium, mercuric chloride, and aristolochic acid; heme pigments; and myeloma light-chain proteins.

A number of pathophysiological mechanisms can contribute to AKI following an ischemic or toxic insult. These include $(a)$ alterations in renal perfusion resulting from loss of autoregulation and increased renal vasoconstriction, $(b)$ tubular dysfunction and cell death by apoptosis and necrosis, $(c)$ desquamation of viable and dead cells contributing to intratubular obstruction, $(d)$ metabolic alterations resulting in transport abnormalities that can lead to abnormalities of tubuloglomerular balance, and $(e)$ local production of inflammatory mediators resulting in interstitial inflammation and vascular congestion $(12,13)$. The processes of injury and repair to the kidney epithelium are depicted schematically in Figure 1. On a cellular level, injury results in rapid loss of cytoskeletal integrity and cell polarity, with mislocalization of adhesion molecules and other membrane proteins such as the $\mathrm{Na}^{+} \mathrm{K}^{+}$ATPase and $\beta$-integrins, shedding of the proximal tubule brush border, as well as apoptosis and necrosis (14). With severe injury, viable and nonviable cells are desquamated, leaving regions where the basement membrane remains as the only barrier between the filtrate and the peritubular interstitium. This allows for backleak of the filtrate, especially under circumstances where the pressure in the tubule is increased owing to intratubular obstruction resulting from cellular debris in the lumen interacting with proteins such as fibronectin that enter the lumen (15). This injury to the epithelium results in the generation of inflammatory and vasoactive mediators, which can act on the vasculature to worsen the vasoconstriction and inflammation. Thus, inflammation contributes in a critical way to the pathophysiology of AKI (16). In contrast to the heart or brain, the kidney efficiently restores cells that were lost owing to an ischemic or toxic insult 
that results in cell death, although it is becoming increasingly recognized that there are longerterm detrimental effects of even brief periods of AKI (17).

Surviving cells that remain adherent contribute to repair. The kidney has the potential to recover a large amount of pre-insult renal function. Whether there is a subpopulation of stem or progenitor cells is a matter of active study at this point in time (18). When the kidney recovers from acute injury it relies on a sequence of events, including epithelial cell spreading and migration to cover the exposed areas of the basement membrane, cell de-differentiation and proliferation to restore cell number, followed by differentiation, which results in restoration of the functional integrity of the nephron (19). The contribution of nontubular progenitor cells to this repair of the tubules is likely to be minimal if any at all (19a). Several studies suggest that there is a very delicate and dynamic relationship between tissue repair and progression or regression of renal injury. A delay or inhibition of nephrogenic tissue repair appears to lead to progression of injury ultimately leading to chronic kidney disease, whereas timely tissue repair may arrest progression of injury, resulting in regression of injury and paving the way for recovery (20).

\section{Diagnosis}

Historically, authors have used various measures to assess renal function and define abnormal function to guide diagnosis. It is estimated that more than 30 different definitions of acute renal failure (now termed AKI) exist in the published literature (21), ranging from severe (ARF requiring dialysis) to mild (modest observable increases in serum creatinine) (22). As a result of the disparate clinical and physiologic endpoints used to guide investigation, epidemiologic studies as well as trials of prevention and intervention are often not comparable. As part of the Acute Dialysis Quality Initiative (ADQI) 2nd International Consensus Conference, the RIFLE classification scheme (risk of kidney dysfunction, injury to the kidney, failure of kidney function, loss of kidney function, and end-stage kidney disease) was derived to provide standardized criteria for defining ARF (22a). In recognition of increasing data suggesting that even small changes in serum creatinine are associated with poorer outcome as measured by mortality, AKIN defined AKI as "an abrupt (within 48 hours) reduction in kidney function currently defined as an absolute increase in serum creatinine of either $\geq 0.3 \mathrm{mg} / \mathrm{dl}$ ( $\geq 25$ micromole/L) or a percentage increase of $\geq 50 \%$ or a reduction in urine output (documented oligouria of $<0.5 \mathrm{ml} / \mathrm{kg} / \mathrm{hr}$ for $>6$ hours)" (23). The RIFLE criteria were modified so that the risk criteria included an absolute increase in serum creatinine $\geq 0.3 \mathrm{mg} \mathrm{dl}^{-1}$ with the new diagnostic criteria in mind (Table 1).

One prevailing weakness with the definition is that it is still entirely based on an increase in serum creatinine or decrease in urine volume; unfortunately, creatinine is a suboptimal marker following injury, when levels are often not reflective of glomerular filtration rate (GFR) owing to a number of renal and nonrenal influences on creatinine levels. In the setting of AKI, the delay between changes in serum creatinine and changes in GFR inhibits the ability to accurately estimate timing of injury and severity of dysfunction following injury (24). A sudden fall in GFR to a constant low level causes a gradual increase in serum creatinine until a new steady state between generation and excretion is achieved. The rate of rise of serum creatinine following AKI is dependent on many factors, including the new GFR, rate of tubular secretion, rate of generation, and volume of distribution $(24,25)$. As a result, large changes in GFR may be associated with relatively small changes in serum creatinine in the first $24-48 \mathrm{~h}$ following AKI, resulting not only in delayed diagnosis and intervention but also in underestimation of the degree of injury. In addition, there is considerable variability among patients in the correlation between serum creatinine and baseline GFR, in the magnitude of functional renal reserve, and in creatinine synthesis rates. As a result, a renal injury of comparable magnitude may result in disparate alterations in creatinine concentration in different individuals (26). 
There is an urgent need for better biomarkers to permit more timely diagnosis of AKI, prediction of injury severity, and safety assessment during drug development. Better biomarkers will help drug developers make more informed decisions about which products to move forward in testing, which doses to test, and how to design clinical trials that will provide clear information about product benefit and safety. Results from interventional trials suggesting lack of efficacy of putative therapies of AKI are, by definition, confounded by delayed diagnosis and treatment. This paradigm of late recognition and/or treatment attempts is analogous to the futility of initiation of therapy directed toward acute ischemia in patients with myocardial infarction or stroke $48 \mathrm{~h}$ after the onset of ischemia (27).

\section{BIOMARKERS OF ACUTE KIDNEY INJURY}

Accessible markers of AKI can be components of serum or urine or can be imaging studies or any other quantifiable parameter. The urine has yielded the most promising markers for the early detection of AKI and further characterization is anticipated, which will qualify these markers as useful tools for the earlier diagnosis, identification of mechanism of injury, and assessment of site and severity of injury (Figure 2, Table 2). Hopefully, one or more of these biomarkers, either alone or in combination, will prove to be useful in facilitating early diagnosis, guiding targeted intervention and monitoring disease progression and resolution.

\section{$\mathrm{N}$-acetyl- $\beta$-glucosaminidase}

$\mathrm{N}$-acetyl- $\beta$-glucosaminidase (NAG), a proximal tubule lysosomal enzyme, has been extensively studied and has proven to be a sensitive, persistent, and robust indicator of tubular injury. Increased NAG levels have been reported with nephrotoxicant exposure (28), delayed renal allograft function, chronic glomerular disease, diabetic nephropathy (29), as well as following cardiopulmonary bypass procedures (30). Westhuyzen et al. (31) reported that urinary NAG levels (in addition to other tubular enzymes) were highly sensitive in detecting AKI in a population of critically ill adult patients, preceding increases in serum creatinine by $12 \mathrm{~h}$ to 4 days. Chew et al. (32) reported a poorer outcome [death in hospital, requirement for long-term renal replacement therapy (RRT)] in patients with higher urinary NAG levels on admission to a renal care unit. The higher the urinary NAG concentrations in patients already diagnosed using AKI clinical criteria, the greater the incidence of the combined endpoint of dialysis or death (33). The two advantages of using NAG are (a) sensitivity, subtle alterations in the epithelial cells in the brush border of the proximal tubules result in shedding of NAG into the urine and the amount of shed enzyme can be directly correlated to tubular injury; and (b) quantitation, simple and reproducible enzymatic assays are well established to measure the analyte colorimetrically using a spectrophotometer. The disadvantage is that urinary NAG activity has been found to be inhibited by endogenous urea (34) as well as a number of nephrotoxicants and heavy metals (35). In addition, increased urinary NAG levels have been reported in a variety of conditions in the absence of clinically significant AKI, including rheumatoid arthritis (35a), impaired glucose tolerance (35b), and hyperthyroidism (35c). As a result, nonspecificity may limit the use of NAG levels as a biomarker of AKI.

\section{$\beta_{2}$-microglobulin}

$\beta_{2}$-microglobulin $\left(\beta_{2} \mathrm{M}\right)$ is an 11.8 - $\mathrm{kDa}$ protein that is the light chain of the major histocompatibility class (MHC) I molecule expressed on the cell surface of all nucleated cells. $\beta_{2} \mathrm{M}$ dissociates from the heavy chain in the setting of cellular turnover and enters the circulation as a monomer (36). $\beta_{2} \mathrm{M}$ is typically filtered by the glomerulus and almost entirely reabsorbed and catabolized by the proximal tubular cells (37), a process that may be impeded in AKI. Increased urinary $\beta_{2} \mathrm{M}$ excretion has been observed to be an early marker of tubular injury in a number of settings, including nephrotoxicant exposure (38), cardiac surgery (39), and renal transplantation (40), preceding rises in serum creatinine by as many as $4-5$ days 
(36). Unfortunately, the utility of $\beta_{2} \mathrm{M}$ as a biomarker has been limited by its instability in urine, with rapid degradation observed at room temperature and in urine with a $\mathrm{pH}$ less than 6.0 (40a). Schaub et al. (40) recently identified cleaved urinary $\beta_{2} \mathrm{M}$ as a potential biomarker of tubular injury in renal allografts; however, assays for protein quantification have not been developed. It should also be noted that although $\beta_{2} \mathrm{M}$ may serve as an early biomarker for AKI, it has been found to be poorly predictive of severe injury requiring RRT (41).

\section{$\alpha_{1}$-microglobulin}

$\alpha_{1}$-microglobulin $\left(\alpha_{1} M\right)$ is a $27-33-k D a$ protein synthesized by the liver with approximately half of the circulating protein complexed to IgA. The free form is readily filtered by the glomerulus and reabsorbed by proximal tubule cells. Unlike $\beta_{2} \mathrm{M}$, urinary $\alpha_{1} \mathrm{M}$ is stable over the range of $\mathrm{pH}$ found in routine clinical practice, making it a preferred marker of tubular proteinuria in human bioassays (28). It has been found to be a sensitive biomarker for proximal tubular dysfunction even in the early phase of injury when no histologic damage is observable (42). In a heterogeneous population of patients with nonoliguric AKI, Herget-Rosenthal et al. reported $\alpha_{1} \mathrm{M}$ to be an early indicator of unfavorable outcome (requirement for RRT) (41). In addition, urinary $\alpha_{1} \mathrm{M}$ has been proposed to be a useful marker of tubular dysfunction even in low-gestational-age preterm infants, a population at high risk for AKI (43). Although sensitive immunoassays have been developed for the quantification of $\alpha_{1} \mathrm{M}$, international standardization is lacking. In addition, a number of conditions have been associated with altered plasma/serum levels, including liver disease, HIV, and mood disorders (43a), and therefore urinary specificity and sensitivity for AKI may be suboptimal in these settings.

\section{Retinol Binding Protein}

Retinol binding protein (RBP) is a $21-\mathrm{kDa}$ protein that is hepatically synthesized and responsible for transporting vitamin A from the liver to other tissues. It is freely filtered by the glomerulus and subsequently reabsorbed and catabolized by the proximal tubule. Bernard et al. (44) monitored patients with AKI from various etiologies and found urinary RBP to be a highly sensitive indicator of renal tubule dysfunction, preceding urinary NAG elevation. They reported RBP and $\beta_{2} \mathrm{M}$ levels to be highly correlated when urinary $\mathrm{pH}>6.0$, with progressively increasing $\mathrm{RBP} / \mathrm{\beta}_{2} \mathrm{M}$ ratios as urinary $\mathrm{pH}$ declined, reflecting RBPs stability in acidic urine when compared with the instability of $\beta_{2} \mathrm{M}$ (44). In addition, Roberts et al. (45) reported that increased RBP levels during the first two days of life were predictive of clinically significant AKI in infants following birth asphyxia, a setting where interpretation of serum creatinine is particularly problematic as it reflects maternal serum concentration to a significant extent. An increased level of urinary RBP has been reported to be an early diagnostic marker of renal injury in cisplatin-, lead-, mercury-, cadmium-, and cyclosporine-induced nephrotoxicity in patients (45a). Serum RBP levels are depressed in vitamin A deficiency, and urinary levels may theoretically yield a false negative result in this setting (36). RBP, $\beta_{2} \mathrm{M}$, and $\alpha_{1} \mathrm{M}$ levels in the urine are measured by immunonephelometric methods using a nephelometer. The utility of low-molecular-weight filtered proteins, such as RBP, $\beta_{2} \mathrm{M}, \alpha_{1} \mathrm{M}$, Cystatin C, and microalbumin (see below), as biomarkers in the setting of AKI is limited by concomitant significant glomerular proteinuria or hyperfiltration, situations where the tubular reabsorptive pathways may be saturated (45b). Furthermore, specificity for AKI is suboptimal.

\section{Cystatin-C}

Cystatin-C (Cys-C) is a 13-kDa protein that was initially known as interalia $\gamma$-trace, post- $\gamma$ globulin, and gamma-CSF and is believed to be one of the most important extracellular inhibitors of cysteine proteases. Serum concentrations appear to be independent of sex, age, and muscle mass. Cys-C is freely filtered by the glomerulus, reabsorbed and catabolized, but not secreted, by the tubules. Over the past decade, serum Cys-C has been extensively studied 
and found to be a sensitive serum marker of GFR and a stronger predictor than serum creatinine of risk of death and cardiovascular events in older patients (46). The only rodent study in which Cys-C was measured was in the rat model of end-stage renal failure in which sequential bilateral nephrectomy was carried out seven days apart. The kinetics of changes in serum Cys-C and creatinine concentrations mimicked the clinical condition (47). Urinary Cys-C levels have been found to be elevated in individuals with known tubular dysfunction $(48,49)$. In addition, HergetRosenthal et al. reported that elevated urinary Cys-C levels were highly predictive of poor outcome (requirement for RRT) in a heterogeneous group of patients with initially nonoliguric AKI (50). The measurement of serum Cys-C before 1994 was performed by using an enzymeamplified single radial immunodif-fusion technique that required at least $10-20 \mathrm{~h}$ and had a relatively high coefficient of variation $(>10 \%)$. Subsequently, automated rapid particleenhanced immunoturbidi-metric and immunonephelometric methods were developed that were more precise and were thus approved by the FDA (51). Recently, an automatic quantitative assay to measure urinary Cys-C has also been developed using an N-Latex Cystatin-C kit with a nephelometer (48).

\section{Microalbumin}

Microalbuminuria, defined as the pathologic excretion of urinary albumin at levels (30 to 300 $\mathrm{mg} / \mathrm{L}$ ) below the threshold of detection by conventional urinary dipstick, has long been established as a useful marker of the development and progression of renal disease, particularly diabetic nephropathy. Historically, microalbuminuria has been assumed to result from alterations in glomerular filtration secondary to changes in intraglomerular pressure and/or structural changes of the podocyte or glomerular basement membrane. Recent evidence in rats, however, suggests that the normal glomerular filter actually may leak albumin at higher levels than previously thought, and albuminuria may result from failure of the proximal tubule cell retrieval pathway (48a). Microalbuminuria may prove to be a useful marker of AKI and concomitant proximal tubular cell damage. Microalbuminuria has previously been reported with short- and long-term administration of nephrotoxic chemotherapeutics such as cisplatin, ifosfamide, and methotrexate (48b,48c), as well as antibiotics such as gentamicin (48d). Using microalbuminuria as a marker, Leven et al. (48e) demonstrated that $\mathrm{N}$-acetylcysteine may attenuate contrast-induced glomerular and tubular injury. Microalbuminuria, however, may also be caused by vigorous exercise, hematuria, urinary tract infection, and dehydration. Additional studies are necessary to further characterize microalbuminuria in the setting of AKI, especially with respect to its sensitivity and specificity.

\section{Kidney Injury Molecule-1}

Kidney injury molecule-1 (KIM-1) is a type I cell membrane glycoprotein containing a unique six-cysteine immunoglobulin-like domain and a mucin domain in its extracellular region. Rat and human cDNAs encoding KIM-1 (Kim-1 in the rodent) were initially identified by our group using representational difference analysis, a polymerase chain reaction-based cDNA subtraction analysis designed to identify genes with differential expression between normal and regenerating kidneys following ischemia/reperfusion (I/R) injury (52). KIM-1 mRNA levels increase more than any other known gene after kidney injury. We have found that the ectodomain of KIM-1 is shed from cells in vitro (53) and in vivo into the urine in rodents (54) and humans (55) after proximal tubular injury (Table 3). In preclinical and clinical studies using several mechanistically different models of kidney injury, urinary Kim-1 serves as an earlier diagnostic indicator of kidney injury when compared with any of the conventional biomarkers, e.g., plasma creatinine; BUN; glycosuria; increased proteinuria; or increased urinary NAG, $\gamma$-GT, or AP levels $(54,55)$. We first developed an enzyme-linked immunosorbent assay (ELISA) to measure Kim-1 in rodent and human urine samples, and recently we have developed a more sensitive, high-throughput microbead-based assay to 
quantitate Kim-1 in rat urine (56). This assay has a greater dynamic range and requires less urine volume $(30 \mu \mathrm{l})$ and reagents than the conventional ELISA.

In recently completed studies of eight mechanistically different proximal tubule nephrotoxicants and two different hepatotoxicants in rats, Kim-1 performed very well in identifying proximal tubular toxicity, using histopathology as the gold standard; of 21 urinary markers studied, Kim-1 was found to have the highest sensitivity and specificity (57). Another study demonstrated Kim-1 to be an outstanding biomarker for cadmium nephrotoxicity (57a). Human studies of urinary KIM-1 for the diagnosis of AKI are promising. Han et al. demonstrated marked expression of KIM-1 in kidney biopsy specimens from six patients with acute tubular necrosis, and found elevated urinary levels of KIM-1 within $12 \mathrm{~h}$ after an initial ischemic renal insult, prior to the appearance of casts in the urine (55). Liangos et al. studied urinary KIM-1 and NAG in 201 patients with established AKI and demonstrated that elevated levels of urinary KIM-1 and NAG were significantly associated with the clinical composite endpoint of death or dialysis requirement, even after adjustment for disease severity or comorbidity (57b). Van Timmeren et al. stained for KIM-1 protein in tissue specimens from 102 patients who underwent kidney biopsy for a variety of kidney diseases and showed that a positive KIM-1 staining in dedifferentiated proximal tubular cells correlated with tubulointerstitial fibrosis and inflammation and in subset of patients who underwent urine collection near the time of biopsy urinary KIM-1 levels correlated with tissue expression of KIM-1 (57c). The temporal expression pattern and predictive potential of urinary KIM-1 as compared with other markers in various forms of AKI are subjects of ongoing clinical studies.

\section{Clusterin}

Clusterin is a multifaceted glycoprotein that was first isolated from ram rete testes fluid by Blaschuk, Burdzy, and Fritz in 1983 and so named because of its ability to elicit clustering of Sertoli cells (58). Clusterin is induced in the kidney and urine of rats, dogs, and primates after various forms of preclinical AKI such as ischemia/reperfusion injury $(59,60)$, toxicant-induced kidney injury, unilateral ureteral obstruction, or subtotal nephrectomy (61-63). Clusterin, like Kim-1, is expressed on the dedifferentiated tubular cells after injury and is also induced in polycystic kidney disease (64) and renal cell carcinoma (65). The nuclear form of human clusterin (nCLU) is proapoptotic and the secretory form (sCLU), which is upregulated in response to any molecular stress, is antiapoptotic and prosurvival. There are recent findings that drugs targeting sCLU expression, using antisense oligonucleotides or short interfering double-stranded RNA, may become promising tools for cancer therapy, especially in treatment of cancers that overexpress sCLU, such as kidney, prostate, colon, breast, and lung tumors (65a). Clusterin is measured by radioimmunoassay, and the amount of protein has been correlated with the elevation of serum creatine and urinary NAG in a gentamicin-induced renal injury model in rats (66). Clusterin mRNA and protein levels, however, did not increase until day 5 in a cisplatin-induced renal injury model (67). To date, there is no clinical study demonstrating the use of clusterin as an early diagnostic/prognostic indicator of acute kidney injury in humans.

\section{Neutrophil Gelatinase-Associated Lipocalin}

Human neutrophil gelatinase-associated lipocalin (NGAL) is a $25-\mathrm{kDa}$ protein initially identified bound to gelatinase in specific granules of the neutrophil. NGAL is synthesized during a narrow window of granulocyte maturation in the bone marrow (68), but also may be induced in epithelial cells in the setting of inflammation or malignancy (69). The lipocalin superfamily comprises proteins that are composed of $8 \beta$-strands that form a $\beta$-barrel enclosing a calyx (69a). The calyx binds and transports low-molecular-weight chemicals. NGAL binds the siderophore (enterochelin) in the calyx with high affinity $(0.4 \mathrm{nM})$, and the siderophore traps iron with a high affinity $\left(10^{-49} \mathrm{M}\right)$ with a stoichiometry of protein:siderophore: $\mathrm{Fe}$ of 
1:1:1 (69b). Cowland \& Borregaard demonstrated varying degrees of NGAL gene expression in a number of other human tissues, including the uterus, prostate, salivary gland, lung, trachea, stomach, colon, and kidney (70).

NGAL was identified as being one of the seven genes whose expression was up-regulated more than tenfold within the first few hours after ischemic renal injury in a mouse model (71). Although it was shown that exogenous administration of NGAL protected against ischemic kidney injury in mice (72), lipocalin-2 knockout mice do not exhibit increased sensitivity to bilateral renal ischemia/reperfusion injury (73). NGAL is upregulated and can be detected in the kidney (74) and urine of mice three hours after cisplatin $\left(20 \mathrm{mg} \mathrm{kg}^{-1}\right)$ administration and has been proposed as an early biomarker for diagnosing AKI (75). A prospective study of pediatric patients undergoing cardiopulmonary bypass for cardiac corrective surgery found urinary NGAL to be a powerful early marker of AKI, preceding any increase in serum creatinine by 1-3 days. A similar study of adult patients showed urinary NGAL levels at 1, 3, and $18 \mathrm{~h}$ after cardiac surgery to be significantly higher in patients who went on to develop clinically significant AKI (76). A retrospective analysis of urine samples from patients with diarrhea-associated hemolytic uremic syndrome revealed that normal urinary NGAL excretion during the early stages of hospitalization had a high negative predictive value of the need for dialysis; however, high urinary NGAL levels were not a reliable predictor of need for dialysis (77). It should be noted that serum NGAL levels are known to rise in the setting of a number of inflammatory and infective conditions and NGAL filtered by the glomerulus appears in the urine $(78,79)$. Further studies are required to determine specificity of urinary NGAL for AKI in the setting of sepsis, a condition frequently associated with clinically significant renal injury.

\section{Interleukin-18}

Interleukin-18 (IL-18) is a cytokine that has been identified as an interferon- $\gamma$ (IFN- $\gamma$ )-inducing factor in livers of mice treated with propionobacterium acnes and lipopolysaccharide (80). IL-18 activity has been described in a number of inflammatory diseases across a broad range of tissues, including inflammatory arthritis, multiple sclerosis, inflammatory bowel disease, chronic hepatitis, systemic lupus erythematosis, and psoriasis (81). The precursor form of IL-18 $(24 \mathrm{kDa})$ is enzymatically cleaved by IL-1 $\beta$-converting enzyme to produce mature $18-\mathrm{kDa}$ IL-18 protein (82). Renal IL-18 mRNA levels have been shown to be significantly upregulated following ischemia-reperfusion injury, inflammatory/autoimmune nephritis, and cisplatininduced nephrotoxicity (82a).

Urinary IL-18 levels are elevated in patients with AKI and delayed graft function compared with normal subjects and patients with prerenal azotemia, UTI, chronic renal insufficiency, and nephrotic syndrome (83). Median urinary IL-18 levels were $985 \mathrm{pg} \mathrm{mg}^{-1}$ creatinine on day 1 in patients with delayed graft function, compared with $56 \mathrm{pg} \mathrm{mg}^{-1}$ in patients with prompt graft function. Immunohistochemical staining of renal transplant protocol biopsies revealed constitutive IL-18 expression in the distal tubular epithelium. There was strong positive immunoreactivity in the proximal tubules of patients with acute rejection. There was also strong immunoreactivity in infiltrating leukocytes and endothelium, suggesting upregulation in the setting of immunopathological reactions (84). In a study of critically ill adult patients with acute respiratory distress syndrome (ARDS), increased urinary IL-18 was found to be an early marker of AKI, preceding changes in serum creatinine by 1-2 days, and was an independent predictor of death (85). In these studies, IL-18 was measured with an ELISA using commercially available antibodies.

\section{Cysteine-Rich Protein}

Cysteine-rich protein (Cyr61) is a cysteine-rich, heparin-binding protein that is secreted and is associated with cell surface and the extracellular matrix, biochemical features that resemble 
the Wnt-1 protooncogene and a number of growth factors (86). Cyr61 is a novel ligand for integrins, and signaling through integrin receptors such as $\alpha_{v} \beta_{3}, \alpha_{v} \beta_{5}$, and $\alpha_{6} \beta_{1}$ regulates angiogenesis and tumorigenesis (87). Cyr61 is rapidly induced in the proximal straight tubules of the kidney within 3-6 h after bilateral renal ischemia in the rats. It is also secreted in the urine within 3-6 $\mathrm{h}$ and has been proposed as a potential biomarker for AKI in preclinical and clinical studies (88). There are two main limitations for the use of Cyr61 as a biomarker. Urinary Cyr61 levels are reduced over time despite the continuous progression of injury in the bilateral I/R injury model. Cyr61 has been quantitated in the urine by immunoblotting, which is not a high-throughput and sensitive method of measurement (88). Owing to these limitations, there are few preclinical and clinical studies to define the diagnostic capability of this molecule.

\section{Osteopontin}

Osteopontin (OPN) is also known as the 44-kDa bone phosphoprotein, sialoprotein I, secreted phosphoprotein I, uropontin, and early T-lymphocyte activation-1 (Eta-1) (89). OPN is synthesized at the highest levels in bone and epithelial tissues. OPN is found at very high levels in human urine $\left(21.4 \pm 6.2 \mathrm{mg} \mathrm{g}^{-1}\right.$ of creatinine or $\left.1.9 \mu \mathrm{g} \mathrm{ml}^{-1}\right)$ and is postulated to act as an inhibitor of calcium oxalate formation, helping to prevent mineral precipitation and stone formation (89a). OPN is also associated with a number of other functions, including regulation of osteoclast function during bone formation, tumorigenesis and transformation, and accumulation of macrophages (89b). OPN is expressed in normal mouse and human kidneys, where it is primarily restricted to the thick ascending limbs of the loop of henle and the distal convoluted tubules (90). OPN mRNA and protein were overexpressed in renal biopsies from patients with essential hypertension with decompensated arteriosclerosis in association with expression of $\alpha$-smooth muscle actin by interstitial fibroblasts and increased type IV collagen deposition (91). Similar correlations between OPN induction and inflammation and tubulointerstitial fibrosis were observed with human progressive idiopathic membranous nephropathy, cresentric glomerulonephritis, IgA nephritis, and diffuse proliferative lupus nephritis (92-94). OPN is also significantly upregulated in rodent models of kidney injury/ disease with injury secondary to I/R injury, gentamicin, cisplatin, cyclosporine, sevoflurane, angiotensin II-induced tubulointerstitial nephritis, puromycin-induced glomerulonephritis, anti Thy-1 nephritis, passive heyman nephritis, protein-overload models of fibrosis, unilateral ureteral obstruction, remnant kidneys in a 5/6 nephrectomy model, and streptozotocin-induced type I diabetes (95). Recently, a commercially available ELISA has been developed to quantitate OPN in mouse, rat, or human urine, and more studies in rodents and humans are needed to determine whether OPN is an early diagnostic quantitative and sensitive indicator of AKI.

\section{Fatty Acid-Binding Protein}

Fatty acid-binding proteins (FABPs) are small $(15 \mathrm{kDa})$ cytoplasmic proteins abundantly expressed in all tissues with active fatty acid metabolism (96). Two types of FABP have been identified in the human kidney: liver-type FABP (L-FABP) in the proximal tubule and hearttype FABP (H-FABP) in the distal tubule $(97,98)$. Free fatty acids (FFAs) in proximal tubules are bound to cytoplasmic FABPs and transported to mitochondria or peroxisomes, where they are metabolized by $\beta$-oxidation (99). Uri-nary L-FABP has been identified in preclinical and clinical models and has been found to be a potential biomarker in a number of pathologic conditions, including chronic kidney disease, diabetic nephropathy, IgA nephropathy, and contrast nephropathy. Using human L-FABP (hL-FABP) transgenic mice, it has been demonstrated that protein-overload nephropathy and unilateral ureteral obstruction, two models of renal interstitial injury, are associated with increased expression and urinary excretion of L-FABP $(100,101)$. In both injury models, attenuation of tubulointerstitial damage was observed in the transgenic mice when compared with wild-type mice, supporting the notion that L-FABP plays a protective role in the setting of increased renal tubular stress (102). In 
clinical studies, L-FABP has been advocated as a potential biomarker for monitoring progression of chronic kidney disease (CKD). Kamijo et al. reported increasing L-FABP levels with deterioration of renal function in patients with nondiabetic CKD (101). In addition, Nakamura et al. have reported that urinary L-FABP may serve as a noninvasive biomarker to discriminate between IgA nephropathy and thin basement membrane disease (103) as well as a potential predictive marker for contrast-induced nephropathy (104).

Although L-FAPB appears to be an attractive candidate biomarker for a number of renal diseases, additional studies are needed to determine the utility of L-FABP in AKI, especially in the setting of ischemia/reperfusion injury, nephrotoxin exposure, and sepsis.

\section{Sodium/Hydrogen Exchanger Isoform}

The sodium/hydrogen exchanger isoform (NHE3) is the most abundant apical sodium transporter in the renal tubule, responsible for the proximal reabsorption of $60 \%-70 \%$ of filtered sodium and bicarbonate in mice $(105,106)$. NHE3 localizes to the apical membrane and intracellular vesicular compartment of renal proximal tubular cells as well as the apical membrane of the thick and thin ascending limb cells (107). McKee et al. demonstrated that NHE3 was readily detected in the urine of healthy rats in immunoblotting experiments (108). Later studies confirmed the presence of NHE3 in urinary exosomes (109). In a study of 68 critically ill adults, du Cheyron et al. performed semiquantitative immunoblotting on urine membrane fractions and found urinary NHE-3 excretion to be a useful marker in discriminating between control patients, those with prerenal azotemia, those with acute glomerular disease, and those with ischemic/nephrotoxic ATN (105). It was recently reported, however, that specimen storage and processing in this study were suboptimal, possibly resulting in increased degradation and decreased recovery of NHE3 prior to protein quantification (109).

\section{Fetuin A}

Fetuin-A is an acute phase protein synthesized in the liver and secreted into the circulation, where it has been implicated in several diverse functions, including bone resorption, regulation of insulin activity and hepatocyte growth factor activity, response to inflammation, and inhibition of ectopic mineralization (110). Zhou et al. identified urinary exosomal fetuin-A (EF-A) to be markedly increased in rats following cisplatin injection. Urinary EF-A increased greater than 50-fold at day 2 , preceding changes in serum creatinine and histologic evidence of tubule damage by one day, and remained elevated until day 5 , when tubule damage was most severe (111). Increased urinary EF-A was additionally noted following I/R injury, but not in the setting of prerenal azotemia (111). In a limited number of clinical specimens ( $\mathrm{n}=$ 9), urinary EF-A was found to be much higher in ICU patients with AKI compared with ICU patients without AKI and healthy volunteers (111). Immunohistochemical staining localized fetuin-A to the cytoplasm of damaged proximal tubule cells with higher concentrations evident with increasing severity of injury. Although the function of fetuin-A in AKI remains unknown, it may play a role in tubule cell apoptosis.

Significant issues with assay throughput and sensitivity currently complicate the quantification of exosomal-associated proteins, limiting their practical use in large-scale studies of AKI. Published studies have exclusively employed immunoblotting, a labor-intensive and semiquantitative method. In addition, isolation of urinary exosomes requires ultracentrifugation of specimens, a process that takes $1-2 \mathrm{~h}$ and several experimental maneuvers. Fortunately, Cheruvanky et al. (112) recently reported that exosomal isolation may be simplified considerably through the use of a commercially available nanomembrane concentrator. 


\section{METHODS TO QUANTITATE BIOMARKERS}

The traditional method to quantitate urinary enzymes has been enzyme-substrate-based colorimetric assays followed by measurement using a spectrophotometer. As urinary proteins were identified as potential biomarkers of AKI, however, the assay of choice became ELISA, which is based on the detection of an antigen using two epitopically distinct antibodies. There are, however, multiple disadvantages of the ELISA assay: (a) Only one antigen can be detected in one plate; $(b)$ the dynamic range of the assay is usually low, requiring repeat measurements with dilution or concentration of urine samples so that the antigen concentration will fit in to the linear range of the standard curve; $(c)$ the urine sample volume requirement is at least 200 $\mu \mathrm{l}$ per assay (100 $\mu \mathrm{l}$ in duplicate); and $(d)$ at least $5-7 \mathrm{~h}$ are required to get the results.

A recent technique that is an adaptation of an ELISA, using principles similar to a flow cytometer, is a particle-based flow cytometric assay developed by Luminex ${ }^{\circledR}$ that uses a microfluidics platform incorporating $5.6-\mu \mathrm{m}$ beads coupled with the primary (capture) antibody (113). Each microsphere is labeled with a precise ratio of red- and orange-emitting fluorochromes, giving it a unique spectral signature. Classification of each bead is determined with an excitation wavelength of $635 \mathrm{~nm}$ and measurement of the emission wavelengths, together with the intensities, of each dye. Quantification is achieved by addition of a biotinylated secondary antibody and streptavidin coupled to a third fluorochrome (phycoerythrin), which is excited at $532 \mathrm{~nm}$ using a second laser. The signal is directly proportional to the amount of antigen bound at the microbead surface.

We recently developed a microbead-based assay to measure urinary KIM-1 and NGAL in patients with acute kidney injury and found that the dynamic range was linear up to five orders of magnitude using only $30 \mu \mathrm{l}$ of urine, with intra- and interassay variability less than $20 \%$ (V. Vaidya and J. Bonventre, unpublished data). Another important advantage of this technique is its multiplexing capability. Theoretically, one is capable of quantitating up to 100 different antigens (owing to the unique spectral signature of each bead) in the same biological sample simultaneously. Researchers have thus far successfully used this technology to quantitate 15 -18 different analytes in the same biological sample $(113,114)$. In the urine, this technology has been often used to measure cytokines; however, customized assays have also been developed to quantitate CXCR3-binding chemokines (Mig/CXCL9, IP-10/CXCL10, and ITAC/CXCL11) as indicators of acute renal allograft dysfunction (115). This technique has also been used to measure beta-amyloid, total tau (T-TAU), and hyperphosphorylated tau (PTAU) in cerebrospinal fluid as biomarkers for Alzheimer's disease (116). Both the ELISA and the microbead-based assay require two epitopically distinct, high-affinity antibodies.

Recently, with advances in nanotechnology, it has been possible to detect antigens using just one capture antibody with a read-out that is based on the principle of a change in conductance (117) owing to antigen binding to the antibody. A silicon nanowire sensor array has been developed that incorporates silicon nanowires covalently coupled with the capture antibody for the respective antigen $(117,118)$. In the process of nanowire fabrication, the conventional gate metal electrode of a field-effect transistor is replaced by the aldehyde-amino covalent bonding of antibodies on top of the silicon oxide layer. The source and drain remain as nickel metal electrodes. In a microfluidic channel, antigen solution flows onto the chip surface, where antigens bind to the respective monoclonal antibodies covalently coupled to the nanowires.

Depending on the charge of the antigen [positive (p-type) or negative n-type)], carriers in the channel between source and drain increase or decrease (depending on if they are p-type or ntype, respectively), and therefore increase or decrease the conductance of the transistor (119). The conductance is easily measurable and a change in conductance is directly related to the amount of antigens bound. Such a multiplexed electrical detection nanowire sensor array was used to detect prostate-specific antigen (PSA), PSA- $\alpha 1$-antichymotrypsin, carcinoembryonic 
antigen, and mucin-1 in serum for the diagnosis of prostate cancer (118). This technology is in its initial stages and requires additional evaluation and validation, but this general approach offers significant advantages over the existing technology: $(a)$ its sensitivity is in the femtomolar range, $(b)$ it requires only one antibody as opposed to two epitopically distinct antibodies; $(c)$ it produces a read-out within minutes as opposed to hours; and $(d)$ it can be adapted as a bedside technology for patient care in hospitals.

\section{CONCLUSIONS}

AKI is a common and devastating condition associated with significant morbidity and mortality. Efforts to identify biomarkers to assist with the early diagnosis of AKI have yielded many promising candidates, such as KIM-1, NGAL, IL-18, Cys-C, clusterin, FABP, and osteopontin. A single biomarker may not be adequate to define AKI given inherent renal heterogeneity and the disparate settings under which kidney injury occurs $(120,121)$. Qualification of biomarkers will require large, well-designed prospective studies comparing multiple biomarkers in the same set of urine samples over extended time courses. Such studies will allow temporal patterns of biomarker elevation to be established, patterns that may be specific to the mechanism of injury (nephrotoxicant, ischemia, allograft rejection, etc.), population of interest (elderly, pediatric, etc.), and/or co-occurring disease states (diabetes, heart disease, sepsis, etc.). As the utility of a biomarker or biomarker panel emerges for the detection of AKI, considerable effort will need to be directed toward developing technologies that will permit the rapid detection and quantification necessary in clinical practice. Biomarkers have the potential to transform the way we diagnose and treat patients with AKI.

\section{SUMMARY POINTS}

1. Acute kidney injury is a complex condition and over the past 50 years, mortality rates have remained essentially unchanged at approximately $50 \%-70 \%$.

2. The pathophysiological mechanisms that can contribute to AKI due to toxins or changes in renal hemodynamics include alterations in renal perfusion resulting from loss of autoregulation and increased renal vasoconstriction; tubular dysfunction resulting from structural changes, metabolic alterations, loss of cell polarity, cell death; abnormalities of tubuloglomerular balance; and a proinflammatory milieu further compromising microvascular perfusion and decline of oxygen and nutrients to the tubules. There is a very delicate and dynamic relationship between renal injury and tissue repair, which governs the progression or regression of renal injury that determines the ultimate outcome.

3. Traditional blood (creatinine, blood urea nitrogen) and urine markers of kidney injury (epithelial cells, tubular casts, fractional excretion of $\mathrm{Na}^{+}$, urinary concentrating ability, etc.) are insensitive and nonspecific for the diagnosis of AKI.

4. To date, most studies have emphasized discovery, characterization, and validation of several highly promising individual biomarkers using models of kidney injury in animals or varied states in humans. Future research should be aimed at evaluating and validating these biomarkers individually and in a multiplexed manner to define (a) preclinical and clinical sensitivity and specificity; $(b)$ time course of elevation in the urine after kidney damage; $(c)$ the correlation with renal tubular damage; and $(d)$ predictions of long and short term outcomes. At a practical level, it is important to define urine preservation techniques and characteristics of the urine that interfere with the measurement of each biomarker. Finally, optimal use of biomarkers requires quantitative algorithms that will take advantage of multiple biomarkers to predict onset of AKI and its outcome and facilitate timely intervention. 
5. Future research should also be directed toward developing and validating highthroughput technologies for biomarker quantitation, with an ultimate goal of having a bedside technology to provide online noninvasive detection of the onset and severity of kidney injury.

\section{ACKNOWLEDGMENTS}

V.S. Vaidya is supported by Scientist Development Grant $0535492 \mathrm{~T}$ from the American Heart Association; M.A. Ferguson is a fellow of the National Kidney Foundation; and J.V. Bonventre is supported by NIH grants DK39773, DK74099, and DK72381.

\section{LITERATURE CITED}

1. Warnock DG. Towards a definition and classification of acute kidney injury. J. Am. Soc. Nephrol 2005;16:3149-50. [PubMed: 16207828]

2. Mehta RL, Kellum JA, Shah SV, Molitoris BA, Ronco C, et al. Acute Kidney Injury Network: report of an initiative to improve outcomes in acute kidney injury. Crit. Care 2007;11:R31. [PubMed: 17331245]

3. Chertow GM, Lee J, Kuperman GJ, Burdick E, Horsky J, et al. Guided medication dosing for inpatients with renal insufficiency. JAMA 2001;286:2839-44. [PubMed: 11735759]

4. Liangos O, Wald R, O'Bell JW, Price L, Pereira BJ, Jaber BL. Epidemiology and outcomes of acute renal failure in hospitalized patients: a national survey. Clin. J. Am. Soc. Nephrol 2006;1:43-51. [PubMed: 17699189]

5. de Mendonca A, Vincent JL, Suter PM, Moreno R, Dearden NM, et al. Acute renal failure in the ICU: risk factors and outcome evaluated by the SOFA score. Intensive Care Med 2000;26:915-21. [PubMed: 10990106]

6. Waikar SS, Curhan GC, Wald R, McCarthy EP, Chertow GM. Declining mortality in patients with acute renal failure, 1988 to 2002. J. Am. Soc. Nephrol 2006;17:1143-50. [PubMed: 16495376]

7. Uchino S, Kellum JA, Bellomo R, Doig GS, Morimatsu H, et al. Acute renal failure in critically ill patients: a multinational, multicenter study. JAMA 2005;294:813-18. [PubMed: 16106006]

8. Nash K, Hafeez A, Hou S. Hospital-acquired renal insufficiency. Am. J. Kidney Dis 2002;39:930-36. [PubMed: 11979336]

9. Thadhani R, Pascual M, Bonventre JV. Acute renal failure. N. Engl. J. Med 1996;334:1448-60. [PubMed: 8618585]

10. Choudhury D, Ziauddin A. Drug-associated renal dysfunction and injury. Nat. Clin. Pract. Nephrol 2005;2:80-91. [PubMed: 16932399]

11. Kleinknecht D, Landais P, Goldfarb B. Drug-associated acute renal failure. A prospective collaborative study of 81 biopsied patients. Adv. Exp. Med. Biol 1987;212:125-28. [PubMed: 3618352]

12. Bonventre JV, Weinberg JM. Recent advances in the pathophysiology of ischemic acute renal failure. J. Am. Soc. Nephrol 2003;14:2199-210. [PubMed: 12874476]

13. Schrier RW, Wang W, Poole B, Mitra A. Acute renal failure: definitions, diagnosis, pathogenesis, and therapy. J. Clin. Invest 2004;114:5-14. [PubMed: 15232604]

14. Zuk A, Bonventre JV, Brown D, Matlin KS. Polarity, integrin, and extracellular matrix dynamics in the postischemic rat kidney. Am. J. Physiol. Cell Physiol 1998;275:C711-31.

15. Zuk A, Bonventre JV, Matlin KS. Expression of fibronectin splice variants in the postischemic rat kidney. Am. J. Physiol. Renal. Physiol 2001;280:F1037-53. [PubMed: 11352844]

16. Bonventre JV, Zuk A. Ischemic acute renal failure: an inflammatory disease? Kidney Int 2004;66:480-85. [PubMed: 15253693]

17. Park KM, Byun JY, Kramers C, Kim JI, Huang PL, Bonventre JV. Inducible nitric-oxide synthase is an important contributor to prolonged protective effects of ischemic preconditioning in the mouse kidney. J. Biol. Chem 2003;278:27256-66. [PubMed: 12682064] 
18. Humphreys BD, Bonventre JV. The contribution of adult stem cells to renal repair. Nephrol. Ther 2007;3:3-10. [PubMed: 17383586]

19. Bonventre JV. Dedifferentiation and proliferation of surviving epithelial cells in acute renal failure. J. Am. Soc. Nephrol 2003;14(Suppl 1):S55-61. [PubMed: 12761240]

19a. Humphreys BD, Bonventre JV. Mesenchymal stem cells in acute kidney injury. Annu. Rev. Med 2008;59:325-39.

20. Vaidya VS, Shankar K, Lock EA, Bucci TJ, Mehendale HM. Renal injury and repair following S-1, 2 dichlorovinyl-L-cysteine administration to mice. Toxicol. Appl. Pharmacol 2003;188:110-21. [PubMed: 12691729]

21. Kellum JA, Levin N, Bouman C, Lameire N. Developing a consensus classification system for acute renal failure. Curr. Opin. Crit. Care 2002;8:509-14. [PubMed: 12454534]

22. Mehta RL, Chertow GM. Acute renal failure definitions and classification: time for change? J. Am. Soc. Nephrol 2003;14:2178-87. [PubMed: 12874474]

22a. Bellomo R, Ronco C, Kellum JA, Mehta RL, Palevsky P. Acute renal failure-definition, outcome measures, animal models, fluid therapy and information technology needs: the Second International Consensus Conference of the Acute Dialysis Quality Initiative (ADQI) Group. Crit. Care 2004;8:R204-12. [PubMed: 15312219]

23. Mehta, RL.; Kellum, JA.; Shah, S.; Molitoris, BA.; Ronco, C., et al. AKIN Summit. AKIN Comm; Amsterdam: 2006. AKIN: Acute Kidney Injury Network: report of an initiative..

24. Moran SM, Myers BD. Course of acute renal failure studied by a model of creatinine kinetics. Kidney Int 1985;27:928-37. [PubMed: 4021321]

25. Star RA. Treatment of acute renal failure. Kidney Int 1998;54:1817-31. [PubMed: 9853246]

26. Bellomo R, Ronco C, Kellum JA, Mehta RL, Palevsky P. Acute renal failure-definition, outcome measures, animal models, fluid therapy and information technology needs: the Second International Consensus Conference of the Acute Dialysis Quality Initiative (ADQI) Group. Crit. Care 2004;8:R204-12. [PubMed: 15312219]

27. Vaidya VS, Bonventre JV. Mechanistic biomarkers for cytotoxic acute kidney injury. Expert. Opin. Drug. Metab. Toxicol 2006;2:697-713. [PubMed: 17014390]

28. Emeigh Hart SG. Assessment of renal injury in vivo. J. Pharmacol. Toxicol. Methods 2005;52:3045. [PubMed: 15953738]

29. Ikenaga H, Suzuki H, Ishii N, Itoh H, Saruta T. Enzymuria in noninsulin-dependent diabetic patients: signs of tubular cell dysfunction. Clin. Sci. (London) 1993;84:469-75. [PubMed: 8097685]

30. Ascione R, Lloyd CT, Underwood MJ, Gomes WJ, Angelini GD. On-pump versus off-pump coronary revascularization: evaluation of renal function. Ann. Thorac. Surg 1999;68:493-98. [PubMed: 10475418]

31. Westhuyzen J, Endre ZH, Reece G, Reith DM, Saltissi D, Morgan TJ. Measurement of tubular enzymuria facilitates early detection of acute renal impairment in the intensive care unit. Nephrol. Dial. Transplant 2003;18:543-51. [PubMed: 12584277]

32. Chew SL, Lins RL, Daelemans R, Nuyts GD, De Broe ME. Urinary enzymes in acute renal failure. Nephrol. Dial. Transplant 1993;8:507-11. [PubMed: 8394530]

33. Liangos O, Perianayagam MC, Vaidya VS, Han WK, Wald R, et al. Urinary N-acetyl-beta-(D)glucosaminidase activity and kidney injury molecule-1 level are associated with adverse outcomes in acute renal failure. J. Am. Soc. Nephrol 2007;18:904-12. [PubMed: 17267747]

34. Bondiou MT, Bourbouze R, Bernard M, Percheron F, Perez-Gonzalez N, Cabezas JA. Inhibition of A and B N-acetyl-beta-D-glucosaminidase urinary isoenzymes by urea. Clin. Chim. Acta 1985;149:67-73. [PubMed: 4028434]

35. Vaidya VS, Shankar K, Lock EA, Bucci TJ, Mehendale HM. Role of tissue repair in survival from s-(1,2-dichlorovinyl)-L-cysteine-induced acute renal tubular necrosis in the mouse. Toxicol. Sci 2003;74:215-27. [PubMed: 12730612]

35a. Iqbal MP, Ali AA, Waqar MA, Mehboobali N. Urinary N-acetyl-beta-D-glucosaminidase in rheumatoid arthritis. Exp. Mol. Med 1998;30:165-69. [PubMed: 9873839]

35b. Fujita H, Narita T, Morii T, Shimotomai T, Yoshioka N, et al. Increased urinary excretion of Nacetylglucosaminidase in subjects with impaired glucose tolerance. Ren. Fail 2002;24:69-75. [PubMed: 11921700] 
35c. Tominaga M, Fujiyama K, Hoshino T, Tanaka Y, Takeuchi T, et al. Urinary N-acetyl-beta-Dglucosaminidase in the patients with hyperthyroidism. Horm. Metab. Res 1989;21:438-40. [PubMed: 2793065]

36. Tolkoff-Rubin NE, Rubin RH, Bonventre JV. Noninvasive renal diagnostic studies. Clin. Lab. Med 1988;8:507-26. [PubMed: 2901937]

37. Miyata T, Jadoul M, Kurokawa K, Van Ypersele de Strihou C. Beta-2 microglobulin in renal disease. J. Am. Soc. Nephrol 1998;9:1723-35. [PubMed: 9727382]

38. Chapelsky MC, Nix DE, Cavanaugh JC, Wilton JH, Norman A, Schentag JJ. Renal tubular enzyme effects of clarithromycin in comparison with gentamicin and placebo in volunteers. Drug. Saf 1992;7:304-9. [PubMed: 1355971]

39. Dehne MG, Boldt J, Heise D, Sablotzki A, Hempelmann G. Tamm-Horsfall protein, alpha-1- and beta-2-microglobulin as kidney function markers in heart surgery. Anaesthesist 1995;44:545-51. [PubMed: 7573902]

40. Schaub S, Wilkins JA, Antonovici M, Krokhin O, Weiler T, et al. Proteomic-based identification of cleaved urinary beta2-microglobulin as a potential marker for acute tubular injury in renal allografts. Am. J. Transplant 2005;5:729-38. [PubMed: 15760396]

40a. Davey PG, Gosling P. Beta 2-microglobulin instability in pathological urine. Clin. Chem 1982;28:1330-33. [PubMed: 6176371]

41. Herget-Rosenthal S, Poppen D, Husing J, Marggraf G, Pietruck F, et al. Prognostic value of tubular proteinuria and enzymuria in nonoliguric acute tubular necrosis. Clin. Chem 2004;50:552-58. [PubMed: 14709451]

42. Wolf MW, Boldt J. Kidney specific proteins: markers for detection of renal dysfunction after cardiac surgery? Clin. Res. Cardiol. Suppl 2007;2:S103-7.

43. Ojala R, Ala-Houhala M, Harmoinen AP, Luukkaala T, Uotila J, Tammela O. Tubular proteinuria in preterm and full-term infants. Pediatr. Nephrol 2006;21:68-73. [PubMed: 16550364]

43a. Penders J, Delanghe JR. Alpha 1-microglobulin: clinical laboratory aspects and applications. Clin. Chim. Acta 2004;346:107-18. [PubMed: 15256311]

44. Bernard AM, Vyskocil AA, Mahieu P, Lauwerys RR. Assessment of urinary retinol-binding protein as an index of proximal tubular injury. Clin. Chem 1987;33:775-79. [PubMed: 3297418]

45. Roberts DS, Haycock GB, Dalton RN, Turner C, Tomlinson P, et al. Prediction of acute renal failure after birth asphyxia. Arch. Dis. Child 1990;65:1021-28. [PubMed: 2241220]

45a. Garcon G, Leleu B, Zerimech F, Marez T, Haguenoer JM, et al. Biologic markers of oxidative stress and nephrotoxicity as studied in biomonitoring of adverse effects of occupational exposure to lead and cadmium. J. Occup. Environ. Med 2004;46:1180-6. [PubMed: 15534506]

45b. D'Amico G, Bazzi C. Urinary protein and enzyme excretion as markers of tubular damage. Curr. Opin. Nephrol. Hypertens 2003;12:639-43. [PubMed: 14564202]

46. Shlipak MG, Sarnak MJ, Katz R, Fried LF, Seliger SL, et al. Cystatin C and the risk of death and cardiovascular events among elderly persons. N. Engl. J. Med 2005;352:2049-60. [PubMed: 15901858]

47. Bokenkamp A, Ciarimboli G, Dieterich C. Cystatin C in a rat model of end-stage renal failure. Ren. Fail 2001;23:431-38. [PubMed: 11499558]

48. Conti M, Moutereau S, Zater M, Lallali K, Durrbach A, et al. Urinary cystatin C as a specific marker of tubular dysfunction. Clin. Chem. Lab. Med 2006;44:288-91. [PubMed: 16519600]

48a. Russo LM, Sandoval RM, McKee M, Osicka TM, Collins AB, et al. The normal kidney filters nephrotic levels of albumin retrieved by proximal tubule cells: retrieval is disrupted in nephrotic states. Kidney Int 2007;71:504-13. [PubMed: 17228368]

48b. Kern W, Braess J, Kaufmann CC, Wilde S, Schleyer E, Hiddemann W. Microalbuminuria during cisplatin therapy: relation with pharmacokinetics and implications for nephroprotection. Anticancer Res 2000;20:3679-88. [PubMed: 11268439]

48c. Koch Nogueira PC, Hadj-Aissa A, Schell M, Dubourg L, Brunat-Mentigny M, Cochat P. Long-term nephrotoxicity of cisplatin, ifosfamide, and methotrexate in osteosarcoma. Pediatr. Nephrol 1998;12:572-75. [PubMed: 9761357] 
48d. Tugay S, Bircan Z, Caglayan C, Arisoy AE, Gokalp AS. Acute effects of gentamicin on glomerular and tubular functions in preterm neonates. Pediatr. Nephrol 2006;21:1389-92. [PubMed: 16897006]

48e. Levin A, Pate GE, Shalansky S, Al-Shamari A, Webb JG, et al. N-acetylcysteine reduces urinary albumin excretion following contrast administration: evidence of biological effect. Nephrol. Dial. Transplant 2007;22:2520-24. [PubMed: 17557777]

49. Uchida K, Gotoh A. Measurement of cystatin-C and creatinine in urine. Clin. Chim. Acta 2002;323:121-28. [PubMed: 12135813]

50. Herget-Rosenthal S, Pietruck F, Volbracht L, Philipp T, Kribben A. Serum cystatin C-a superior marker of rapidly reduced glomerular filtration after uninephrectomy in kidney donors compared to creatinine. Clin. Nephrol 2005;64:41-46. [PubMed: 16047644]

51. Kyhse-Andersen J, Schmidt C, Nordin G, Andersson B, Nilsson-Ehle P, et al. Serum cystatin C, determined by a rapid, automated particle-enhanced turbidimetric method, is a better marker than serum creatinine for glomerular filtration rate. Clin. Chem 1994;40:1921-26. [PubMed: 7923773]

52. Ichimura T, Bonventre JV, Bailly V, Wei H, Hession CA, et al. Kidney injury molecule-1 (KIM-1), a putative epithelial cell adhesion molecule containing a novel immunoglobulin domain, is upregulated in renal cells after injury. J. Biol. Chem 1998;273:4135-42. [PubMed: 9461608]

53. Bailly V, Zhang Z, Meier W, Cate R, Sanicola M, Bonventre JV. Shedding of kidney injury molecule-1, a putative adhesion protein involved in renal regeneration. J. Biol. Chem 2002;277:39739-48. [PubMed: 12138159]

54. Vaidya VS, Ramirez V, Ichimura T, Bobadilla NA, Bonventre JV. Urinary kidney injury molecule-1: a sensitive quantitative biomarker for early detection of kidney tubular injury. Am. J. Physiol. Renal Physiol 2006;290:F517-29. [PubMed: 16174863]

55. Han WK, Bailly V, Abichandani R, Thadhani R, Bonventre JV. Kidney injury molecule-1 (KIM-1): a novel biomarker for human renal proximal tubule injury. Kidney Int 2002;62:237-44. [PubMed: 12081583]

56. Vaidya VS, Ramirez V, Bobadilla NA, Bonventre JV. A microfluidics based assay to measure Kidney injury molecule-1 (Kim-1) in the urine as a biomarker for early diagnosis of acute kidney injury. J. Am. Soc. Nephrol 2005;16:192A.

57. Dieterle F, Staedtler F, Grenet O, Cordier A, Perentes E, et al. Qualification of biomarkers for regulatory decision making - a kidney safety biomarker project. Toxicol. Off. J. Soc. Toxicol 2007;96:381.

57a. Prozialeck WC, Vaidya VS, Liu J, Waalkes MP, Edwards JR, et al. Kidney injury molecule-1 is an early biomarker of cadmium nephrotoxicity. Kidney Int 2007;72:985-93. [PubMed: 17687258]

57b. Liangos O, Perianayagam MC, Vaidya VS, Han WK, Wald R, et al. Urinary N-acetyl-beta-(D)glucosaminidase activity and kidney injury molecule-1 level are associated with adverse outcomes in acute renal failure. J. Am. Soc. Nephrol 2007;18:904-12. [PubMed: 17267747]

57c. van Timmeren MM, van den Heuvel MC, Bailly V, Bakker SJ, van Goor H, Stegeman CA. Tubular kidney injury molecule-1 (KIM-1) in human renal disease. J. Pathol 2007;212:209-17. [PubMed: 17471468]

58. Blaschuk O, Burdzy K, Fritz IB. Purification and characterization of a cell-aggregating factor (clusterin), the major glycoprotein in ram rete testis fluid. J. Biol. Chem 1983;258:7714-20. [PubMed: 6863260]

59. Rosenberg ME, Paller MS. Differential gene expression in the recovery from ischemic renal injury. Kidney Int 1991;39:1156-61. [PubMed: 1910124]

60. Witzgall R, Brown D, Schwarz C, Bonventre JV. Localization of proliferating cell nuclear antigen, vimentin, c-Fos, and clusterin in the postischemic kidney. Evidence for a heterogenous genetic response among nephron segments, and a large pool of mitotically active and dedifferentiated cells. J. Clin. Invest 1994;93:2175-88. [PubMed: 7910173]

61. Chevalier RL. Growth factors and apoptosis in neonatal ureteral obstruction. J. Am. Soc. Nephrol 1996;7:1098-105. [PubMed: 8866400]

62. Davis JW 2nd, Goodsaid FM, Bral CM, Obert LA, Mandakas G, et al. Quantitative gene expression analysis in a nonhuman primate model of antibiotic-induced nephrotoxicity. Toxicol. Appl. Pharmacol 2004;200:16-26. [PubMed: 15451304] 
63. Kharasch ED, Schroeder JL, Bammler T, Beyer R, Srinouanprachanh S. Gene expression profiling of nephrotoxicity from the sevoflurane degradation product fluoromethyl-2,2-difluoro-1(trifluoromethyl)vinyl ether ("Compound A") in rats. Toxicol. Sci 2006;90:419-31. [PubMed: 16384817]

64. Harding MA, Chadwick LJ, Gattone VH 2nd, Calvet JP. The SGP-2 gene is developmentally regulated in the mouse kidney and abnormally expressed in collecting duct cysts in polycystic kidney disease. Dev. Biol 1991;146:483-90. [PubMed: 1864465]

65. Correa-Rotter R, Ibarra-Rubio ME, Schwochau G, Cruz C, Silkensen JR, et al. Induction of clusterin in tubules of nephrotic rats. J. Am. Soc. Nephrol 1998;9:33-37. [PubMed: 9440084]

65a. Shannan B, Seifert M, Leskov K, Willis J, Boothman D, et al. Challenge and promise: roles for clusterin in pathogenesis, progression and therapy of cancer. Cell Death Differ 2006;13:12-19. [PubMed: 16179938]

66. Aulitzky WK, Schlegel PN, Wu DF, Cheng CY, Chen CL, et al. Measurement of urinary clusterin as an index of nephrotoxicity. Proc. Soc. Exp. Biol. Med 1992;199:93-96. [PubMed: 1728043]

67. Silkensen JR, Agarwal A, Nath KA, Manivel JC, Rosenberg ME. Temporal induction of clusterin in cisplatin nephrotoxicity. J. Am. Soc. Nephrol 1997;8:302-5. [PubMed: 9048350]

68. Borregaard N, Sehested M, Nielsen BS, Sengelov H, Kjeldsen L. Biosynthesis of granule proteins in normal human bone marrow cells. Gelatinase is a marker of terminal neutrophil differentiation. Blood 1995;85:812-17. [PubMed: 7833481]

69. Nielsen BS, Borregaard N, Bundgaard JR, Timshel S, Sehested M, Kjeldsen L. Induction of NGAL synthesis in epithelial cells of human colorectal neoplasia and inflammatory bowel diseases. Gut 1996;38:414-20. [PubMed: 8675096]

69a. Flower DR, North AC, Sansom CE. The lipocalin protein family: structural and sequence overview. Biochim. Biophys. Acta 2000;1482:9-24. [PubMed: 11058743]

69b. Mori K, Lee HT, Rapoport D, Drexler IR, Foster K, et al. Endocytic delivery of lipocalinsiderophore-iron complex rescues the kidney from ischemiareperfusion injury. J. Clin. Invest 2005;115:610-21. [PubMed: 15711640]

70. Cowland JB, Borregaard N. Molecular characterization and pattern of tissue expression of the gene for neutrophil gelatinase-associated lipocalin from humans. Genomics 1997;45:17-23. [PubMed: 9339356]

71. Mishra J, Ma Q, Prada A, Mitsnefes M, Zahedi K, et al. Identification of neutrophil gelatinaseassociated lipocalin as a novel early urinary biomarker for ischemic renal injury. J. Am. Soc. Nephrol 2003;14:2534-43. [PubMed: 14514731]

72. Mori K, Lee HT, Rapoport D, Drexler IR, Foster K, et al. Endocytic delivery of lipocalin-siderophoreiron complex rescues the kidney from ischemiareperfusion injury. J. Clin. Invest 2005;115:610-21. [PubMed: 15711640]

73. Berger T, Togawa A, Duncan GS, Elia AJ, You-Ten A, et al. Lipocalin 2-deficient mice exhibit increased sensitivity to Escherichia coli infection but not to ischemia-reperfusion injury. Proc. Natl. Acad. Sci. USA 2006;103:1834-39. [PubMed: 16446425]

74. Matthaeus T, Schulze-Lohoff E, Ichimura T, Weber M, Andreucci M, et al. Co-regulation of neutrophil gelatinase-associated lipocalin and matrix metalloproteinase-9 in the postischemic rat kidney. J. Am. Soc. Nephrol 2001;12:787A.

75. Mishra J, Mori K, Ma Q, Kelly C, Barasch J, Devarajan P. Neutrophil gelatinase-associated lipocalin: a novel early urinary biomarker for cisplatin nephrotoxicity. Am. J. Nephrol 2004;24:307-15. [PubMed: 15148457]

76. Wagener G, Jan M, Kim M, Mori K, Barasch JM, et al. Association between increases in urinary neutrophil gelatinase-associated lipocalin and acute renal dysfunction after adult cardiac surgery. Anesthesiology 2006;105:485-91. [PubMed: 16931980]

77. Trachtman H, Christen E, Cnaan A, Patrick J, Mai V, et al. Urinary neutrophil gelatinase-associated lipocalcin in D+HUS: a novel marker of renal injury. Pediatr. Nephrol 2006;21:989-94. [PubMed: 16773412]

78. Ohlsson S, Wieslander J, Segelmark M. Increased circulating levels of proteinase 3 in patients with antineutrophilic cytoplasmic autoantibodies-associated systemic vasculitis in remission. Clin. Exp. Immunol 2003;131:528-35. [PubMed: 12605707] 
79. Xu SY, Pauksen K, Venge P. Serum measurements of human neutrophil lipocalin (HNL) discriminate between acute bacterial and viral infections. Scand. J. Clin. Lab. Invest 1995;55:125-31. [PubMed: 7667605]

80. Nakamura K, Okamura H, Nagata K, Komatsu T, Tamura T. Purification of a factor which provides a costimulatory signal for gamma interferon production. Infect. Immun 1993;61:64-70. [PubMed: 8093360]

81. Gracie JA, Robertson SE, McInnes IB. Interleukin-18. J. Leukoc. Biol 2003;73:213-24. [PubMed: 12554798]

82. Sugawara I. Interleukin-18 (IL-18) and infectious diseases, with special emphasis on diseases induced by intracellular pathogens. Microbes Infect 2000;2:1257-63. [PubMed: 11008115]

82a. Leslie JA, Rink RC, Meldrum KK. The role of interleukin-18 in renal injury. J. Surg. Res. 2007

83. Parikh CR, Jani A, Melnikov VY, Faubel S, Edelstein CL. Urinary interleukin-18 is a marker of human acute tubular necrosis. Am. J. Kidney Dis 2004;43:405-14. [PubMed: 14981598]

84. Striz I, Krasna E, Honsova E, Lacha J, Petrickova K, et al. Interleukin 18 (IL-18) upregulation in acute rejection of kidney allograft. Immunol. Lett 2005;99:30-35. [PubMed: 15894108]

85. Parikh CR, Abraham E, Ancukiewicz M, Edelstein CL. Urine IL-18 is an early diagnostic marker for acute kidney injury and predicts mortality in the intensive care unit. J. Am. Soc. Nephrol 2005;16:3046-52. [PubMed: 16148039]

86. Yang GP, Lau LF. Cyr61, product of a growth factor-inducible immediate early gene, is associated with the extracellular matrix and the cell surface. Cell Growth Differ 1991;2:351-57. [PubMed: 1782153]

87. Perbal B. The CCN family of genes: a brief history. Mol. Pathol 2001;54:103-4. [PubMed: 11322165]

88. Muramatsu Y, Tsujie M, Kohda Y, Pham B, Perantoni AO, et al. Early detection of cysteine rich protein 61 (CYR61, CCN1) in urine following renal ischemic reperfusion injury. Kidney Int 2002;62:1601-10. [PubMed: 12371960]

89. Xie Y, Nishi S, Iguchi S, Imai N, Sakatsume M, et al. Expression of osteopontin in gentamicin-induced acute tubular necrosis and its recovery process. Kidney Int 2001;59:959-74. [PubMed: 11231351]

89a. Asplin JR, Arsenault D, Parks JH, Coe FL, Hoyer JR. Contribution of human uropontin to inhibition of calcium oxalate crystallization. Kidney Int 1998;53:194-99. [PubMed: 9453018]

89b. Xie Y, Sakatsume M, Nishi S, Narita I, Arakawa M, Gejyo F. Expression, roles, receptors, and regulation of osteopontin in the kidney. Kidney Int 2001;60:1645-57. [PubMed: 11703581]

90. Hudkins KL, Giachelli CM, Cui Y, Couser WG, Johnson RJ, Alpers CE. Osteopontin expression in fetal and mature human kidney. J. Am. Soc. Nephrol 1999;10:444-57. [PubMed: 10073594]

91. Thomas SE, Lombardi D, Giachelli C, Bohle A, Johnson RJ. Osteopontin expression, tubulointerstitial disease, and essential hypertension. Am. J. Hypertens 1998;11:954-61. [PubMed: 9715788]

92. Hudkins KL, Giachelli CM, Eitner F, Couser WG, Johnson RJ, Alpers CE. Osteopontin expression in human crescentic glomerulonephritis. Kidney Int 2000;57:105-16. [PubMed: 10620192]

93. Mezzano SA, Droguett MA, Burgos ME, Ardiles LG, Aros CA, et al. Overexpression of chemokines, fibrogenic cytokines, and myofibroblasts in human membranous nephropathy. Kidney Int 2000;57:147-58. [PubMed: 10620196]

94. Okada H, Moriwaki K, Konishi K, Kobayashi T, Sugahara S, et al. Tubular osteopontin expression in human glomerulonephritis and renal vasculitis. Am. J. Kidney Dis 2000;36:498-506. [PubMed: 10977781]

95. Xie Y, Sakatsume M, Nishi S, Narita I, Arakawa M, Gejyo F. Expression, roles, receptors, and regulation of osteopontin in the kidney. Kidney Int 2001;60:1645-57. [PubMed: 11703581]

96. Glatz JF, Van Der Vusse GJ. Cellular fatty acid-binding proteins: their function and physiological significance. Prog. Lipid. Res 1996;35:243-82. [PubMed: 9082452]

97. Maatman RG, van de Westerlo EM, van Kuppevelt TH, Veerkamp JH. Molecular identification of the liver- and the heart-type fatty acid-binding proteins in human and rat kidney. Use of the reverse transcriptase polymerase chain reaction. Biochem. J 1992;288(Pt 1):285-90. [PubMed: 1280113]

98. Maatman RG, Van Kuppevelt TH, Veerkamp JH. Two types of fatty acid-binding protein in human kidney. Isolation, characterization and localization. Biochem. J 1991;273(Pt 3):759-66. [PubMed: 1996972] 
99. Sweetser DA, Heuckeroth RO, Gordon JI. The metabolic significance of mammalian fatty-acidbinding proteins: abundant proteins in search of a function. Annu. Rev. Nutr 1987;7:337-59. [PubMed: 3300738]

100. Kamijo A, Kimura K, Sugaya T, Yamanouchi M, Hikawa A, et al. Urinary fatty acid-binding protein as a new clinical marker of the progression of chronic renal disease. J. Lab. Clin. Med 2004;143:2330. [PubMed: 14749682]

101. Kamijo A, Sugaya T, Hikawa A, Yamanouchi M, Hirata Y, et al. Urinary liver-type fatty acid binding protein as a useful biomarker in chronic kidney disease. Mol. Cell. Biochem 2006;284:175-82. [PubMed: 16532260]

102. Kamijo A, Sugaya T, Hikawa A, Okada M, Okumura F, et al. Urinary excretion of fatty acid-binding protein reflects stress overload on the proximal tubules. Am. J. Pathol 2004;165:1243-55. [PubMed: 15466390]

103. Nakamura T, Sugaya T, Ebihara I, Koide H. Urinary liver-type fatty acid-binding protein: discrimination between IgA nephropathy and thin basement membrane nephropathy. Am. J. Nephrol 2005;25:447-50. [PubMed: 16118482]

104. Nakamura T, Sugaya T, Node K, Ueda Y, Koide H. Urinary excretion of liver-type fatty acid-binding protein in contrast medium-induced nephropathy. Am. J. Kidney Dis 2006;47:439-44. [PubMed: 16490622]

105. du Cheyron D, Daubin C, Poggioli J, Ramakers M, Houillier P, et al. Urinary measurement of Na $+/ \mathrm{H}+$ exchanger isoform 3 (NHE3) protein as new marker of tubule injury in critically ill patients with ARF. Am. J. Kidney Dis 2003;42:497-506. [PubMed: 12955677]

106. Wang T, Yang CL, Abbiati T, Schultheis PJ, Shull GE, et al. Mechanism of proximal tubule bicarbonate absorption in NHE3 null mice. Am. J. Physiol. Renal Physiol 1999;277:F298-302.

107. Eladari D, Leviel F, Pezy F, Paillard M, Chambrey R. Rat proximal NHE3 adapts to chronic acidbase disorders but not to chronic changes in dietary $\mathrm{NaCl}$ intake. Am. J. Physiol. Renal Physiol 2002;282:F835-43. [PubMed: 11934693]

108. McKee JA, Kumar S, Ecelbarger CA, Fernandez-Llama P, Terris J, Knepper MA. Detection of Na (+) transporter proteins in urine. J. Am. Soc. Nephrol 2000;11:2128-32. [PubMed: 11053490]

109. Zhou H, Yuen PS, Pisitkun T, Gonzales PA, Yasuda H, et al. Collection, storage, preservation, and normalization of human urinary exosomes for biomarker discovery. Kidney Int 2006;69:1471-76. [PubMed: 16501490]

110. Denecke B, Graber S, Schafer C, Heiss A, Woltje M, Jahnen-Dechent W. Tissue distribution and activity testing suggest a similar but not identical function of fetuin-B and fetuin-A. Biochem. J 2003;376:135-45. [PubMed: 12943536]

111. Zhou H, Pisitkun T, Aponte A, Yuen PS, Hoffert JD, et al. Exosomal fetuin-A identified by proteomics: a novel urinary biomarker for detecting acute kidney injury. Kidney Int 2006;70:184757. [PubMed: 17021608]

112. Cheruvanky A, Zhou H, Pisitkun T, Kopp JB, Knepper MA, et al. Rapid isolation of urinary exosomal biomarkers using a nanomembrane ultrafiltration concentrator. Am. J. Physiol. Renal Physiol 2007;292(5):F1657-61. [PubMed: 17229675]

113. Carson RT, Vignali DA. Simultaneous quantitation of 15 cytokines using a multiplexed flow cytometric assay. J. Immunol. Methods 1999;227:41-52. [PubMed: 10485253]

114. Vignali DA. Multiplexed particle-based flow cytometric assays. J. Immunol. Methods 2000;243:243-55. [PubMed: 10986418]

115. Hu H, Aizenstein BD, Puchalski A, Burmania JA, Hamawy MM, Knechtle SJ. Elevation of CXCR3binding chemokines in urine indicates acute renal-allograft dysfunction. Am. J. Transplant 2004;4:432-37. [PubMed: 14961998]

116. Olsson A, Vanderstichele H, Andreasen N, De Meyer G, Wallin A, et al. Simultaneous measurement of beta-amyloid(1-42), total tau, and phosphorylated tau (Thr181) in cerebrospinal fluid by the xMAP technology. Clin. Chem 2005;51:336-45. [PubMed: 15563479]

117. Wang WU, Chen C, Lin KH, Fang Y, Lieber CM. Label-free detection of small-molecule-protein interactions by using nanowire nanosensors. Proc. Natl. Acad. Sci. USA 2005;102:3208-12. [PubMed: 15716362] 
118. Zheng G, Patolsky F, Cui Y, Wang WU, Lieber CM. Multiplexed electrical detection of cancer markers with nanowire sensor arrays. Nat. Biotechnol 2005;23:1294-301. [PubMed: 16170313]

119. Patolsky F, Zheng G, Lieber CM. Fabrication of silicon nanowire devices for ultrasensitive, labelfree, real-time detection of biological and chemical species. Nat. Protoc 2006;1:1711-24. [PubMed: 17487154]

120. Fliser D, Novak J, Thongboonkerd V, Argiles A, Jankowski V, et al. Advances in urinary proteome analysis and biomarker discovery. J. Am. Soc. Nephrol 2007;18(4):1057-71. [PubMed: 17329573]

121. Rifai N, Gillette MA, Carr SA. Protein biomarker discovery and validation: the long and uncertain path to clinical utility. Nat. Biotechnol 2006;24:971-83. [PubMed: 16900146] 


\section{a Pathophysiology of AKI}

- Vasoconstriction

- Desquamation of tubular cells

- Intraluminal tubular obstruction resulting in tubular backleak

- Local production of inflammatory mediators resulting in interstitial inflammation, small vessel obstruction, and local ischemia

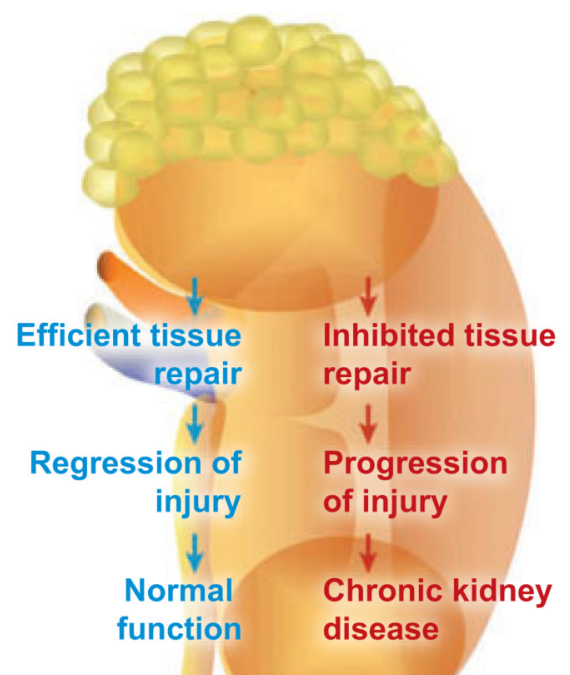

\section{b Cellular level}

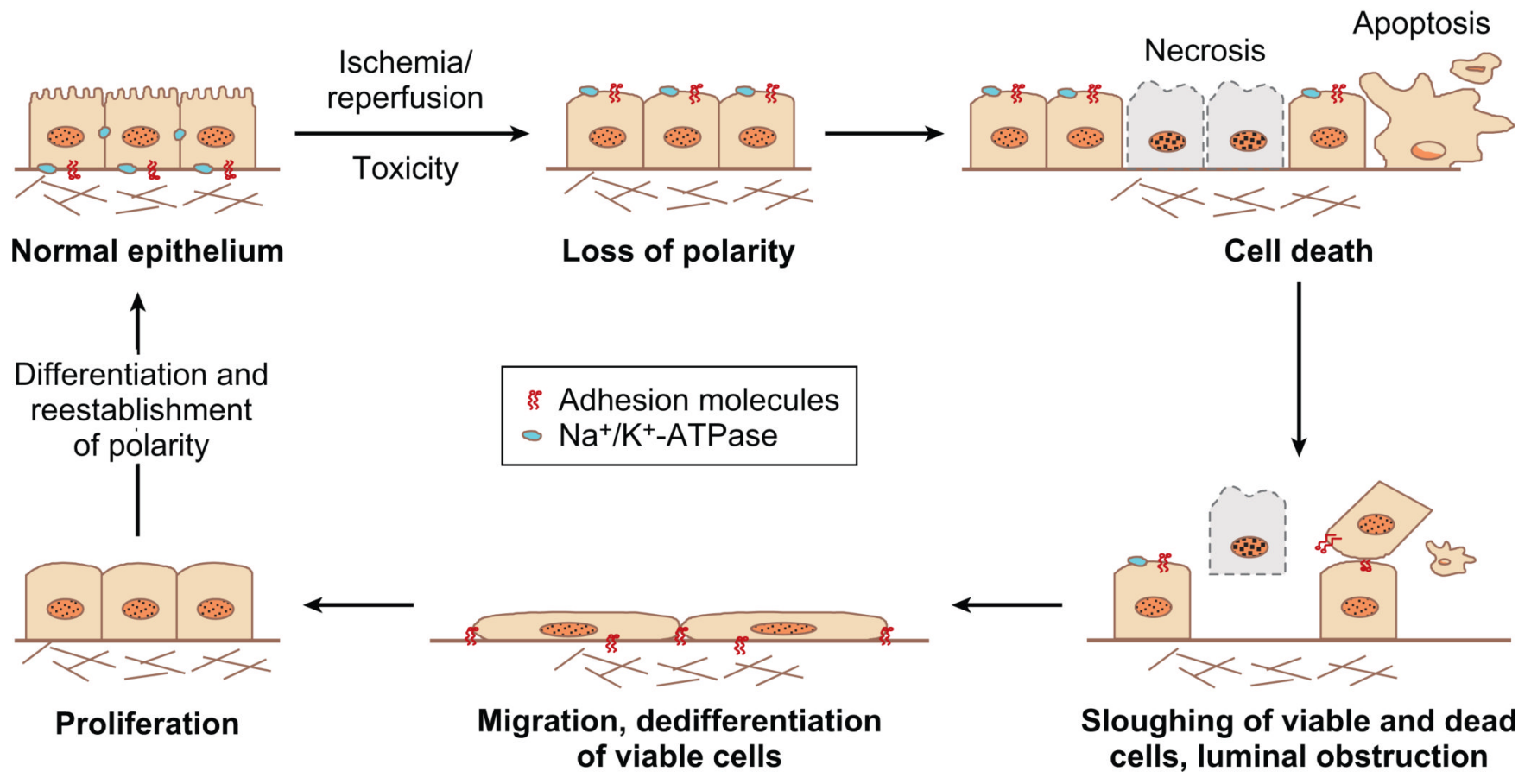

Figure 1.

Schematic representation of (a) pathophysiological and $(b)$ cellular mechanisms of acute kidney injury. 


\section{a Kidney injury continuum}
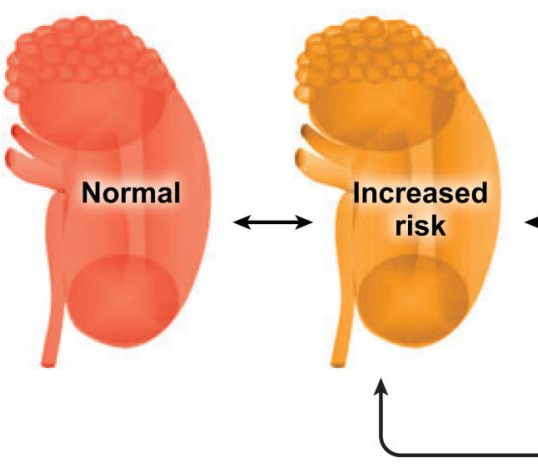

\section{b Biomarkers}

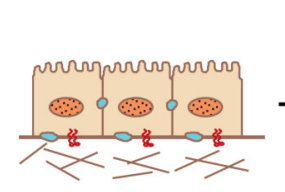

Normal epithelium

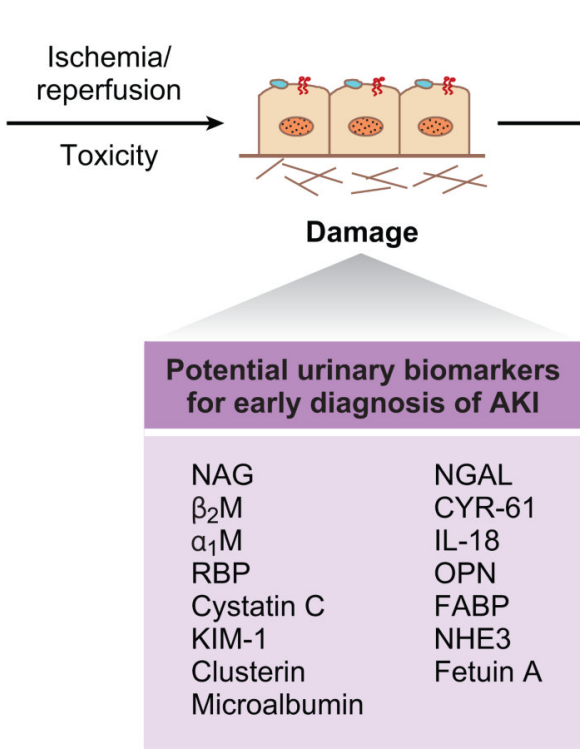

Apoptosis

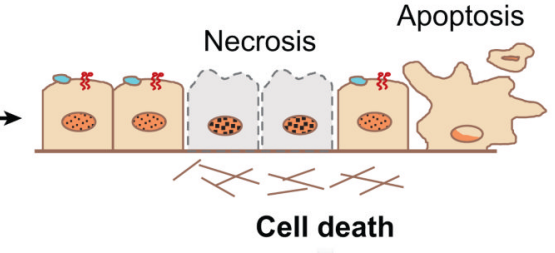

Figure 2.

(a) Kidney injury continuum: The process of acute kidney injury can be divided into various reversible stages depending on the severity of insult, starting from increased risk to damage followed by decrease in glomerular filtration rate (GFR) further progressing to kidney failure and death. Diminished renal perfusion may result in decreased GFR in the absence of intrinsic damage, a condition termed prerenal azotemia. (b) Biomarkers of AKI: Traditionally used markers, such as blood urea nitrogen (BUN) and creatinine (CR), are insensitive, nonspecific, and do not adequately differentiate between the different stages of AKI. A delay in diagnosis prevents timely patient management decisions, including administration of putative therapeutic 
agents. Urinary biomarkers of AKI will facilitate earlier diagnosis and specific preventative and therapeutic strategies, ultimately resulting in fewer complications and improved outcomes. 


\section{Table 1}

Proposed classification scheme for acute kidney injury (AKI) in patients*

\begin{tabular}{|c|c|c|}
\hline Stage & Creatinine criteria & Urine output criteria \\
\hline 1 (Risk) & Increased $\mathrm{SCr}$ of $\geq 0.3 \mathrm{mg} \mathrm{dl}^{-1}$ or increase to $\geq 150 \%-200 \%$ from baseline & $\mathrm{UO}<0.5 \mathrm{ml} \mathrm{kg}^{-1} \mathrm{~h}^{-1}$ for $>6 \mathrm{~h}$ \\
\hline 2 (Injury) & Increased SCr to $>200 \%-300 \%$ & $\mathrm{UO}<0.5 \mathrm{ml} \mathrm{kg}^{-1} \mathrm{~h}^{-1}$ for $>12 \mathrm{~h}$ \\
\hline 3 (Failure) & $\begin{array}{l}\text { Increase } \mathrm{SCr} \text { to }>300 \% \text { from baseline ( } \mathrm{or} \mathrm{Scr} \geq 4 \mathrm{mg} \mathrm{dl}^{-1} \text { ) (acute rise } \geq 0.5 \\
\mathrm{mg} / \mathrm{dl} \text { ) }\end{array}$ & UO $<0.3 \mathrm{ml} \mathrm{kg}^{-1} \mathrm{~h}^{-1} \times 24 \mathrm{~h}$ or Anuria $\times 12 \mathrm{~h}$ \\
\hline \multicolumn{3}{|c|}{ Stages eliminated from the original RIFLE criterion } \\
\hline Loss & \multicolumn{2}{|l|}{ Persistent ARF $=$ complete loss of kidney function $>4$ weeks } \\
\hline ESKD & \multicolumn{2}{|l|}{ End-stage kidney disease (>3 months) } \\
\hline \multicolumn{3}{|c|}{$\begin{array}{l}\text { ARF: Acute renal failure; ESKD: end-stage kidney disease; RIFLE: Risk of renal dysfunction; injury to the kidney; failure of kidney function; loss of } \\
\text { kidney function; end-stage kidney disease; SCr: serum creatinine; UO: urine output. }\end{array}$} \\
\hline
\end{tabular}


Biomarkers of acute kidney injury

Table 2

Bionarkers of acule kidney injury

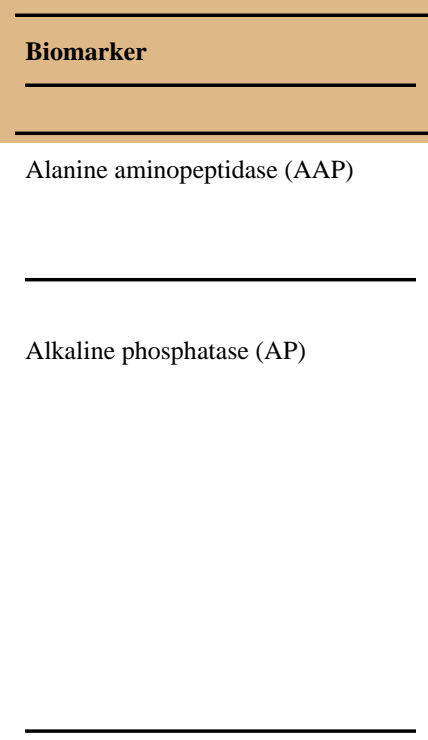

$\alpha$-glutathione-S-transferase ( $\alpha$-GST)

$\gamma$-glutamyl transpeptidase ( $\gamma \mathrm{GT}$ )

N-acetyl- $\beta$-glucosaminidase (NAG) border enzyme

2. Instability may limit clinical utility

\section{Proximal tubule brush border enzyme. Human intestinal alkaline phosphatase is specific for proximal tubular S3 segment; human tissue nonspecific alkaline phosphatase is specific for $\mathrm{S} 1$ and $\mathrm{S} 2$ segments}

2. Levels may not correlate with extent of functional injury

3. Instability may limit clinical utility

1. Proximal tubule cytosolic enzyme

2. Requires stabilization buffer for specimen storage and processing

3. Upregulated in AKI and renal cell carcinoma

\section{Proximal tubule brush} border enzyme

2 . Instability requires samples to be analyzed quickly after collection, limiting clinical utility

1. Proximal tubule lysosomal enzyme

2. More stable than other urinary enzymes

3. Extensive preclinical and clinical data in a variety of conditions (nephrotoxicant exposure, cardiopulmonary bypass, delayed renal allograft function, etc.)

4. Endogenous urea may inhibit activity

1. Light chain of the MHC I molecule expressed on the cell surface of all nucleated cells

2. Monomeric form is filtered by the glomerulus and reabsorbed by the proximal tubule cells

3. Early marker of tubular dysfunction in a variety of conditions
Colorimetry

Rat, human
Species

Rat, dog, human

Colorimetry

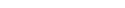




\section{Biomarker}

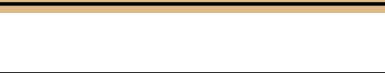

$\alpha_{1}$-microglobulin

Retinol-binding protein (RBP)

Cystatin C

Microalbumin

Kidney injury molecule-1 (KIM-1)

\section{Comments}

Detection

Species

4. Instability in acidic urine limits clinical utility

1. Synthesized by the liver

ELISA, nephelometer

Mouse, rat, human

2. Filtered by the glomerulus and reabsorbed by proximal tubule cells

3. Early marker of tubular dysfunction; high levels may predict poorer outcome

4. Stable across physiologic urinary $\mathrm{pH}$

1. Synthesized by liver, involved in vitamin A

transport

2. Filtered by glomerulus and reabsorbed by proximal tubule cells

3. Early marker of tubular dysfunction

4. Increased stability in acidic urine when compared to $\beta_{2-}$ microglobulin

1. Important extracellular inhibitor of cysteine proteases

2. Filtered by the glomerulus and reabsorbed by proximal tubule cells

3. Elevated urinary levels reflect tubular dysfunction; high levels may predict poore outcome

1. Established marker for monitoring progression of diabetic kidney disease

2. Elevated urinary levels may be indicative of proximal tubular damage

3. Lack of specificity for AKI may limit its utility

1. Type- 1 cell membrane glycoprotein upregulated in dedifferentiated proximal tubule epithelial cells

2. Ectodomain is shed and can be quantitated in urine following acute kidney injury in preclinical and clinical studies

3. Elevated urinary levels are highly sensitive and specific for AKI

4. Upregulated following various models of preclinical and clinical AKI, fibrosis,
ELISA, nephelometer

Mouse, rat, human

ELISA, nephelometer

Mouse, rat, human

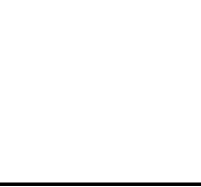

ELISA Immunoturbidimetry

Mouse, rat, dog, monkey, human

ELISA, Luminex®-based assay

Zebrafish, mouse, rat, dog, monkey, human 


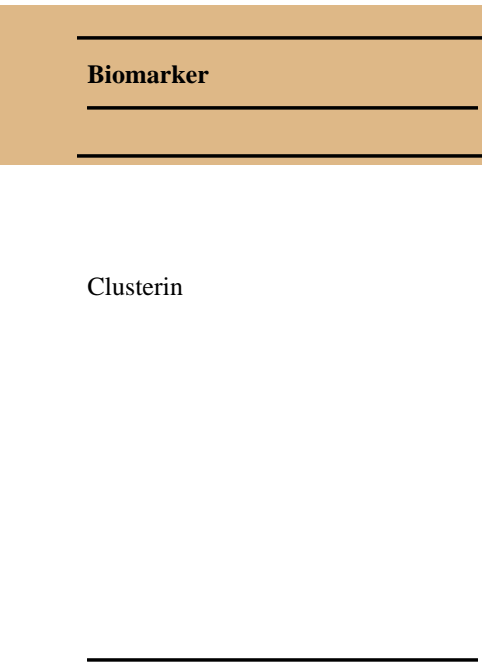

Neutrophil gelatinase associated lipocalin (NGAL)

\section{Interleukin-18 (IL-18)}

Cysteine-rich protein (CYR-61)

$$
\begin{aligned}
& \text { 1. Expressed on } \\
& \text { dedifferentiated tubular } \\
& \text { epithelial cells }
\end{aligned}
$$

Detection

2. Elevated kidney and urinary

levels are very sensitive for AKI in preclinical models

3. Upregulated in various rodent models of AKI, fibrosis, renal cell carcinoma, and polycystic kidney disease

\section{No clinical study}

demonstrating its use

1. Initially identified bound to gelatinase in specific granules of the neutrophils but also may be induced in epithelial cells in the setting of inflammation or malignancy

2. Expression upregulated in kidney proximal tubule cells and urine following ischemic or cisplatin induced renal injury

3. Found to be an early indicator of AKI following cardiopulmonary bypass

4. Specificity for AKI in setting of sepsis; pyuria needs to be further established

1. Cytokine with broad immunomodulatory properties, particularly in setting of ischemic injury

2. Constitutively expressed in distal tubules; strong immunore-activity in proximal tubules with transplant rejection

3. Elevated urinary levels found to be early marker of $\mathrm{AKI}$ and independent predictor of mortality in critically ill patients

1. Induced in proximal straight tubules of kidney and secreted in the urine within 3-6h following ischemic kidney injury

2. Urinary levels decrease rapidly in spite of progression of injury indicating stability issue

3. No clinical study demonstrating its use

4. No quantitative method established
Species

Mouse, rat, dog, monkey, human
ELISA Luminex®-based assay $\quad$ Mouse, rat, human 


\begin{tabular}{|c|c|c|c|}
\hline Biomarker & Comments & Detection & Species \\
\hline & & & \\
\hline \multirow[t]{3}{*}{ Osteopontin (OPN) } & $\begin{array}{l}\text { 1. Upregulated in various } \\
\text { rodent models of AKI }\end{array}$ & ELISA & $\begin{array}{l}\text { Mouse, rat, } \\
\text { monkey, human }\end{array}$ \\
\hline & $\begin{array}{l}\text { 2. The induction correlates } \\
\text { with inflammation and } \\
\text { tubulointerstitial fibrosis }\end{array}$ & & \\
\hline & $\begin{array}{l}\text { 3. No clinical study } \\
\text { demonstrating its use }\end{array}$ & & \\
\hline \multirow[t]{4}{*}{ Fatty acid binding protein (FABP) } & $\begin{array}{l}\text { 1. Expressed in proximal } \\
\text { tubule epithelial cells }\end{array}$ & ELISA & Mouse, rat, human \\
\hline & $\begin{array}{l}\text { 2. Current evidence suggests } \\
\text { clinical utility as a biomarker } \\
\text { in CKD and diabetic } \\
\text { nephropathy }\end{array}$ & & \\
\hline & $\begin{array}{l}\text { 3. Additional studies } \\
\text { necessary to determine utility }\end{array}$ & & \\
\hline & $\begin{array}{l}\text { in setting of preclinical and } \\
\text { clinical AKI }\end{array}$ & & \\
\hline \multirow[t]{4}{*}{$\begin{array}{l}\text { Sodium/hydrogen exchanger isoform } \\
\text { (NHE3) }\end{array}$} & $\begin{array}{l}\text { 1. Most abundant sodium } \\
\text { transporter in the renal tubule }\end{array}$ & Immunoblotting & Mouse, rat, human \\
\hline & $\begin{array}{l}\text { 2. Urinary levels found to } \\
\text { discriminate between prerenal } \\
\text { azotemia and AKI in ICU } \\
\text { patients }\end{array}$ & & \\
\hline & $\begin{array}{l}\text { 3. Samples require } \\
\text { considerable processing, }\end{array}$ & & \\
\hline & limiting assay throughput & & \\
\hline \multirow[t]{5}{*}{ Exosomal fetuin-A } & $\begin{array}{l}\text { 1. Acute phase protein } \\
\text { synthesized in the liver and } \\
\text { secreted into the circulation }\end{array}$ & Immunoblotting & Rat, human \\
\hline & $\begin{array}{l}\text { 2. Levels in proximal tubule } \\
\text { cell cytoplasm correspond to } \\
\text { degree of injury }\end{array}$ & & \\
\hline & $\begin{array}{l}\text { 3. Urinary levels found to be } \\
\text { much higher in ICU patients } \\
\text { with AKI compared to ICU } \\
\text { patients without AKI and } \\
\text { healthy volunteers }\end{array}$ & & \\
\hline & $\begin{array}{l}\text { 4. Samples require } \\
\text { considerable processing, } \\
\text { limiting assay throughput }\end{array}$ & & \\
\hline & $\begin{array}{l}\text { 5. Additional studies } \\
\text { necessary to determine utility } \\
\text { in setting of preclinical and } \\
\text { clinical AKI }\end{array}$ & & \\
\hline
\end{tabular}




\section{Table 3}

Characteristics of Kidney injury molecule-1 (Kim-1)*

\begin{tabular}{|c|c|c|}
\hline Parameters & \multicolumn{2}{|l|}{ Description } \\
\hline Other names & \multicolumn{2}{|c|}{$\begin{array}{l}\text { Hepatitis A virus cellular receptor-1 (HAVCR-1), T cell immunoglobulin like molecule-1 (TIM-1), } \\
\text { cochlear injury molecule-1 (CIM-1) }\end{array}$} \\
\hline Chromosomal location & \multicolumn{2}{|c|}{ Human (5q31), chimpanzee (5), rat (10q21), mouse (11B1.1) } \\
\hline Molecular mass & \multicolumn{2}{|c|}{ Human (359 aa), chimpanzee (predicted: $357 \mathrm{aa),} \mathrm{rat} \mathrm{(307} \mathrm{aa),} \mathrm{mouse} \mathrm{(305} \mathrm{aa)}$} \\
\hline Structure & \multicolumn{2}{|c|}{$\begin{array}{l}\text { Immunoglobulin domain, threonine-serine-proline-rich mucin domain, transmembrane domain, shor } \\
\text { cytoplasmic tail }\end{array}$} \\
\hline Number of KIM-1 homologues & \multicolumn{2}{|c|}{ Human (three: KIM-1, KIM-3, KIM-4), rat (six: Kim-1 to Kim-6), mouse (eight: Kim-1 to Kim-8) } \\
\hline$\%$ Identity of human KIM-1 protein & \multicolumn{2}{|c|}{ Chimpanzee $(79 \%)$, rat $(39 \%)$, mouse $(37 \%)$} \\
\hline \multirow{9}{*}{$\begin{array}{l}\text { Upregulation in kidney injury/ } \\
\text { toxicity/dedifferentiation models }\end{array}$} & Adriamycin-nephrosis & Ischemia/reperfusion \\
\hline & Brain dead donor rat kidney & Kidney fibrosis \\
\hline & Cadmium & Mercuric chloride \\
\hline & Chromium & Ochratoxin \\
\hline & Cisplatin & Polycystic kidney disease \\
\hline & Cyclosporine & Protein-overload \\
\hline & Endotoxin & Renal cell carcinoma \\
\hline & Folic acid & Sevoflurane \\
\hline & Gentamicin & S-(1,1,2,2-tetrafluoroethyl)-1-cysteine (TFEC) \\
\hline
\end{tabular}

